This article has been scanned by iThenticat No plagiarism detected

Volume 3, Issue 6, December 2021

p. $101-117$

\title{
ATTITUDES OF SECONDARY SCHOOL TEACHERS IN EAST JERUSALEM TOWARDS EMPLOYING THE PORTFOLIO AS AN ALTERNATIVE ASSESSMENT TOOL IN TEACHING
}

http://dx.doi.org/10.47832/2757-5403.6-3.8

\section{Mirvat Abu ASABBIGBARIEH ${ }^{1}$ \& Lubna NASRALLA ${ }^{2}$}

\begin{abstract}
:
The study aimed to identify the attitudes of secondary school teachers in East Jerusalem towards employing the achievement file "Portfolio" as an alternative assessment tool in teaching, according to gender variables, years of service, educational material, and the classes they teach. To verify the objectives of the study, the two researchers used the descriptive analytical method by constructing a questionnaire whose number of paragraphs was (15) paragraphs. The questionnaire was applied to a sample of (143) male and female teachers, from the study community consisting of (780) male and female teachers. The results of the study concluded that the attitudes of secondary school teachers in East Jerusalem towards employing the achievement file "Portfolio" as an alternative assessment tool were positive and to a medium degree, and that the overall tool obtained an arithmetic mean of (3. 40), as well as the presence of statistically significant differences due to the variables of gender, years of service and subject education and the classes they teach, came for the benefit of female teachers, long-serving teachers, 12 th grade teachers, and also for teachers of subjects other than science, mathematics and languages.
\end{abstract}

Key words: Attitudes, High Schools in East Jerusalem, Portfolio, Alternative Assessment Tool.

\footnotetext{
${ }^{1}$ Dr. , Arab American University, Palestine, Yossi2007@yahoo.com, https://orcid. org/0000-0002-5988-3288

${ }^{2}$ Dr. , Arab American University, Palestine, lubtamnas@gmail.com, https://orcid. org/0000-0001-9464-9596
} 


\title{
اتجاهات معلمي المرحلة الثانوية في القدس الثرقية نحو توظيف ملف الاتجاز

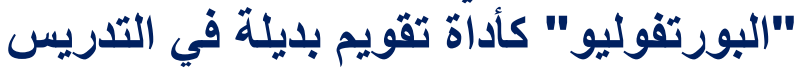

\author{
ميرفت رجب أبوعصب اغبارية 3 \\ لبنى زاهي التّميمي نصر الله 4
}

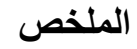

هدفت الدّراسة التعرف على اتجاهات معلمي المرحلة الثانوية في القدس الثرقية نحو

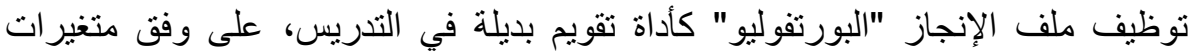

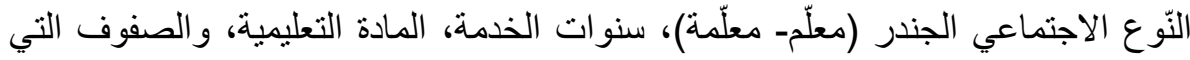

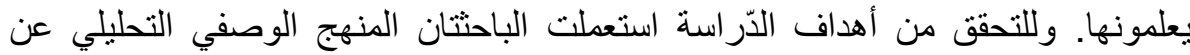
طريق بناء استبانة بلغ عدد فقر اتها (15) فقرة، نم تطبيق الاستبانة على عينة بلغت (143)

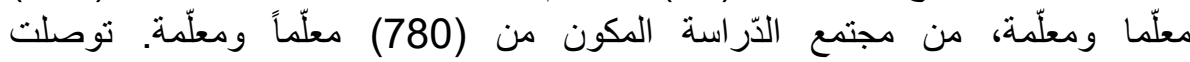

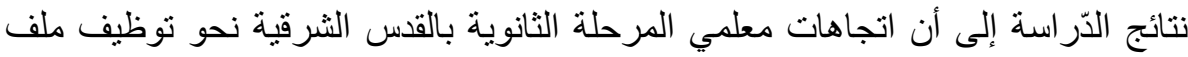

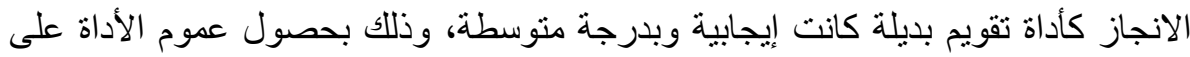

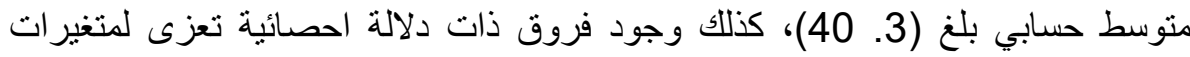

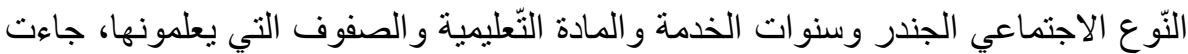

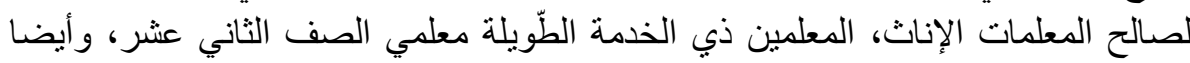

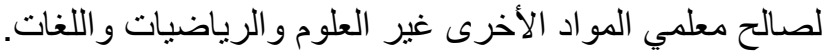

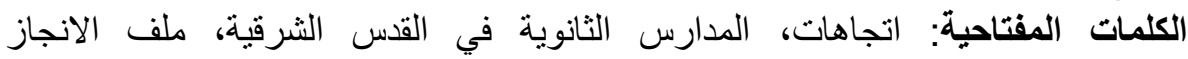
"البورتفوليو"، أدوات التقويم البديلة.
\end{abstract}

المقدمة:

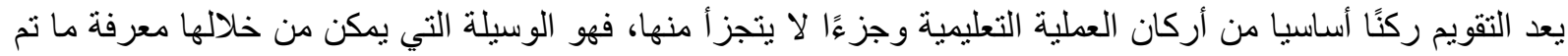

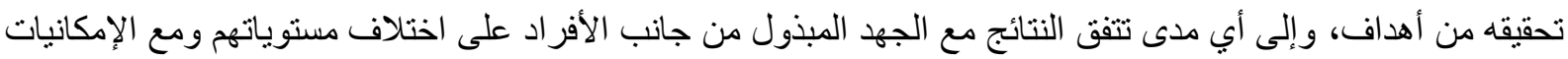

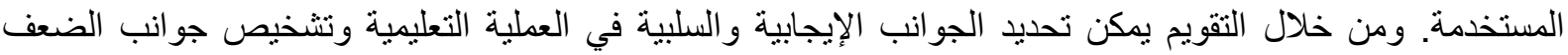
و القصور فيها، وذلك من أجل اتخاذ الإجر اءات المناسبة. يتمثل الهدف الأسمى لعملية التقويم في تحسين العملية التعليمية

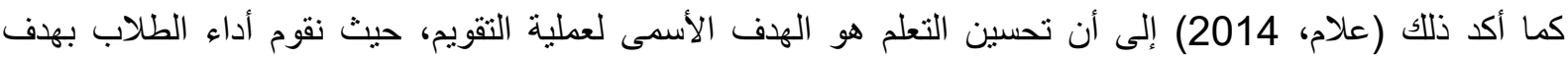

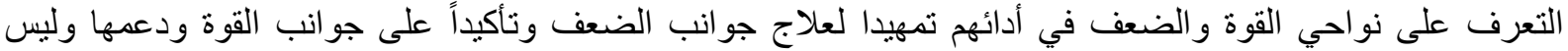

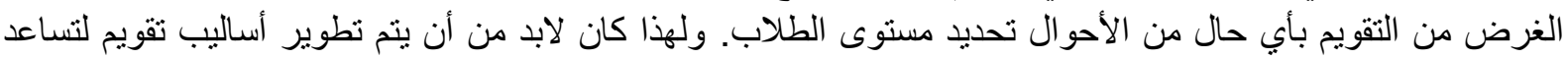

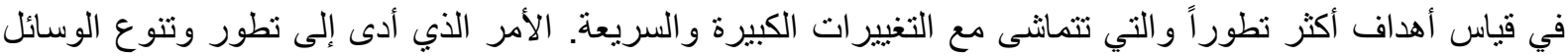

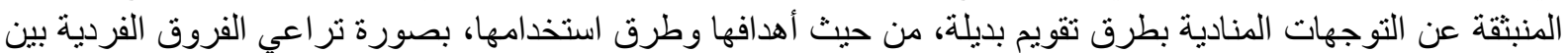

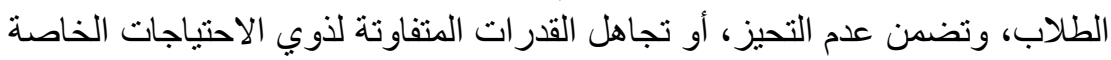

.(McLaughlin \& Lewes, 1994)

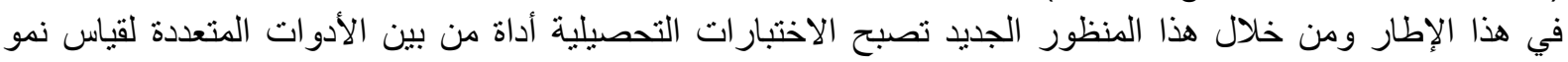

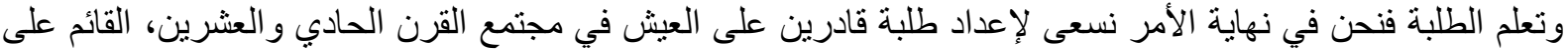

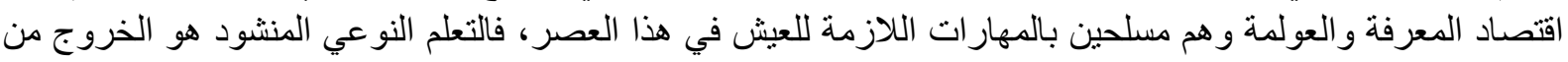

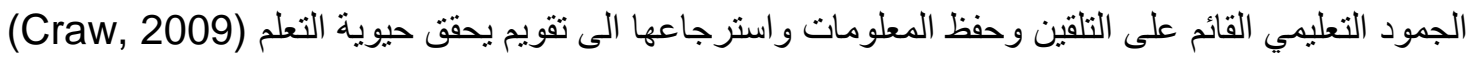

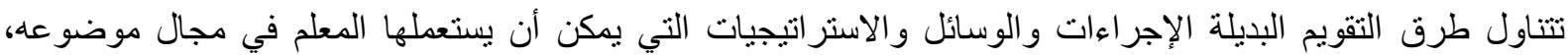

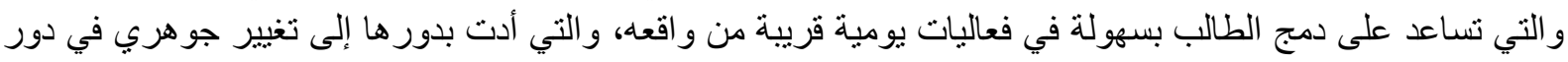


المعلم كموجه ومرشد لطلابه؛ على خلاف ما عرف عنه تاريخياً كملقن للمعلومات. وتعد ملفات الانجاز من التطورات

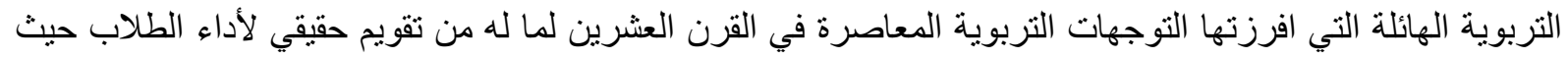

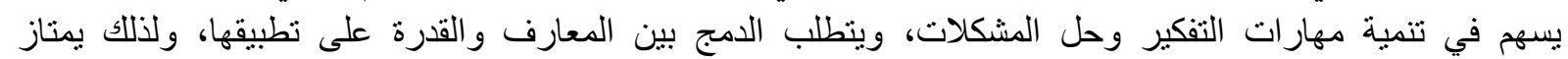

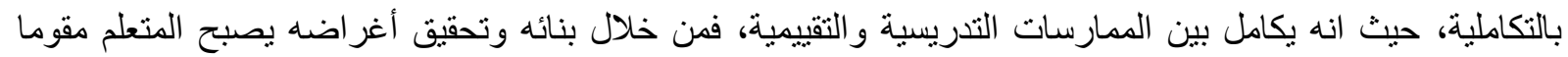

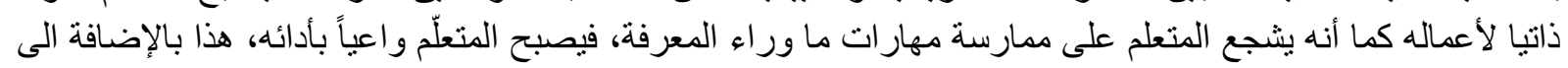

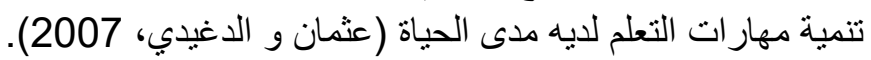

إثكالية الاراسة:

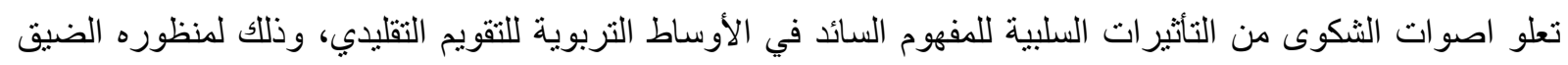

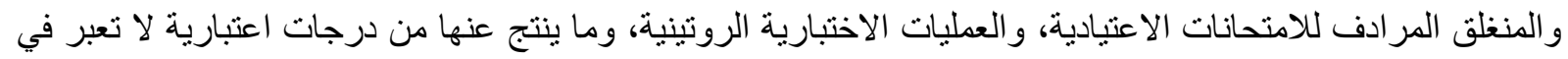

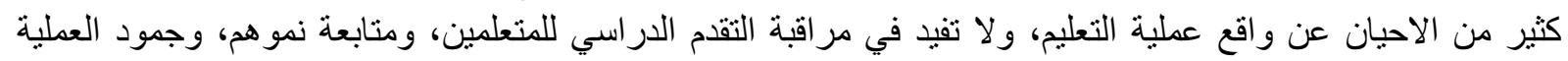

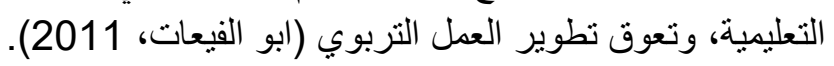

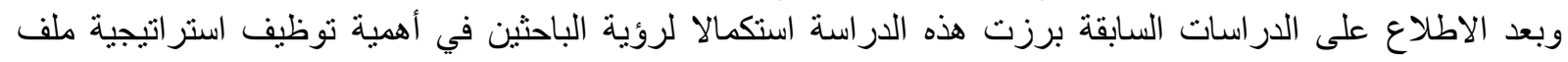

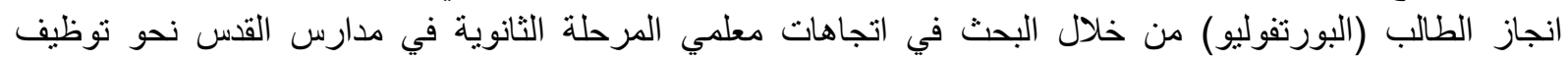

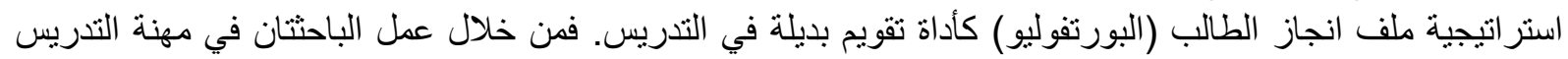

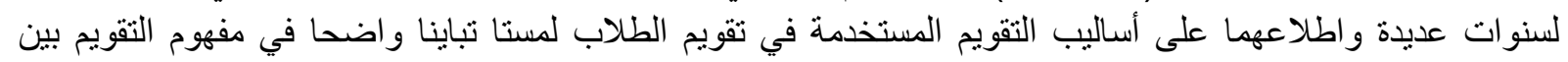

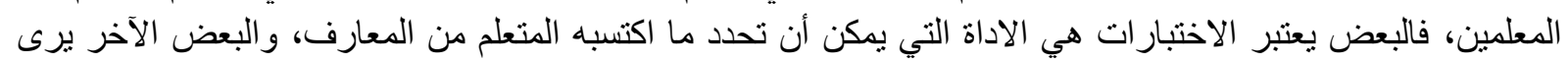

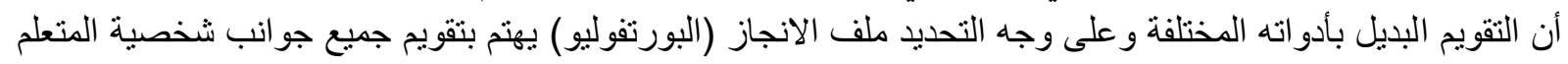

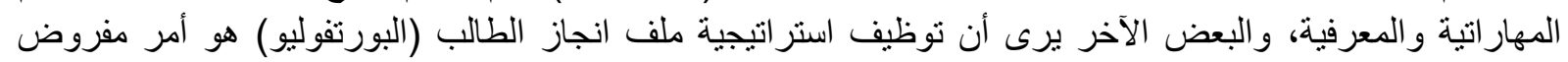

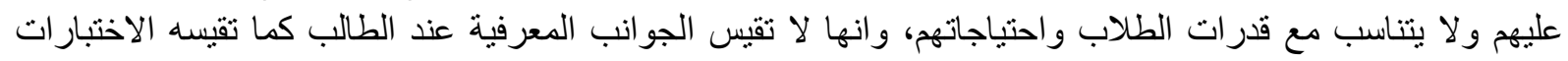

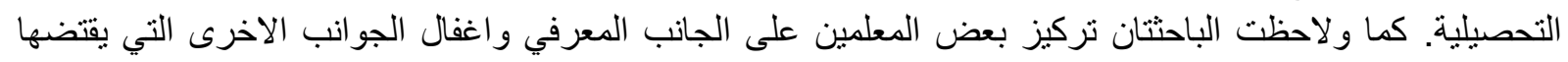

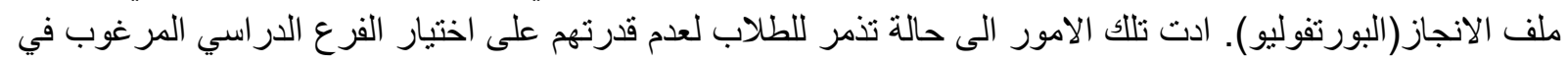

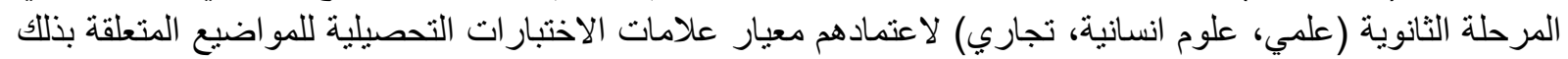

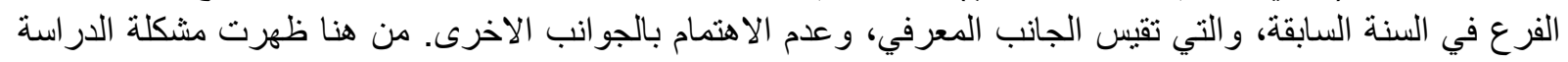

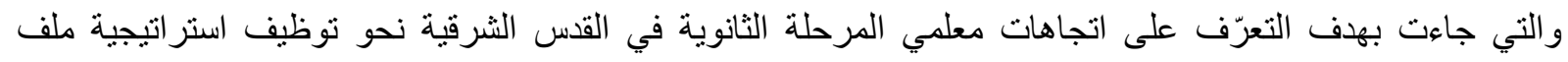

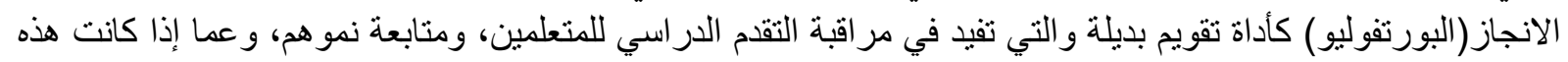

الاتجاهات تختلف باختلاف متغير المادة التعليمية أو سنوات فئ فئ الخبرة.

أسئلة الدّر اسة:

وبناءً على ما تمّ طرحه يمكن تحديد إثكالية الدّر اسة بالسؤال الآتي: ما اتجاهات معلمي المرحلة الثانوية بمدارس القس الثرقية نحو نوظيف ملف الانجاز "البورتفوليو" كأداة تقويم بديلة في بلي التدريس؟ مأجات

وللتحقق من الهدف الرّئيس يتوجب صياغة الفرضيات الآتية:

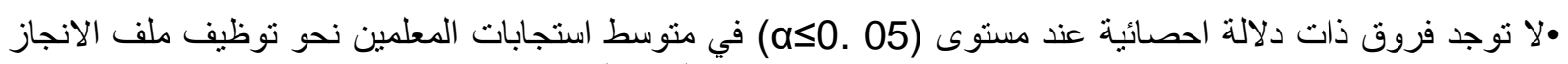

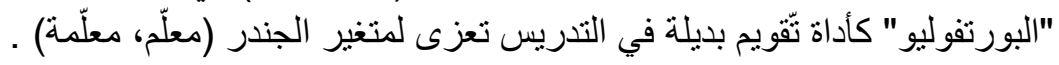

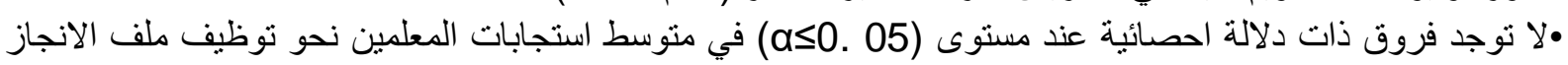

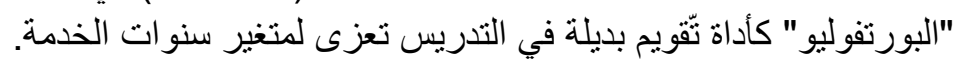

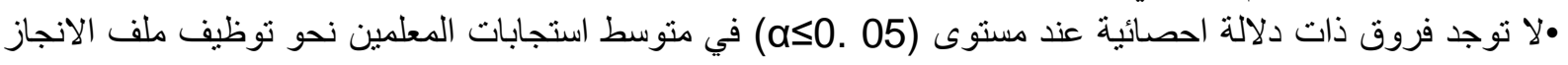

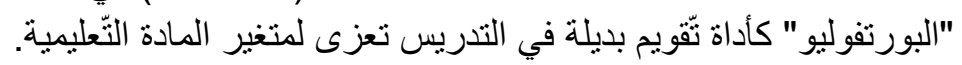

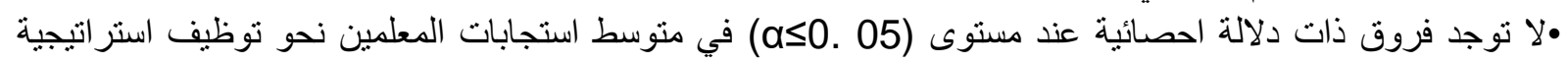

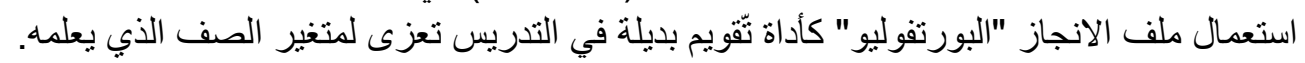


تهدف الدّر اسة إلى استقصاء اتجاهات المعلمين نحو توظيف استر اتيجية استعمال ملف الانجاز "البورتفوليو" كأداة تُّويم بديلة في المدارس الثانوية في مدينة القدس الثرقية.

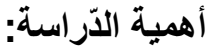
• نوفر اطار انظريا حول استر اتيجية ملف الانجاز كأداة تقويم بديلة في المدارس الثانوية في مدينة القسس الثرقية. وذلك الكي

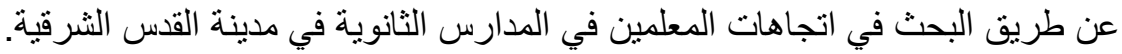

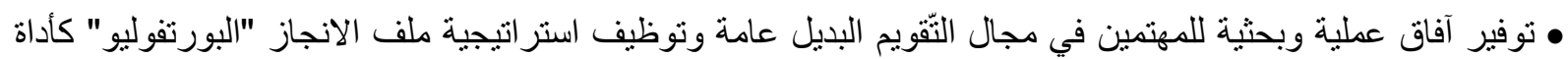

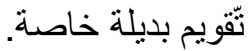
• إسهام نتائج هذه الدّر اسة في ابراز دور ملف الانجاز (البورتفوليو) في مساعدة الطّلبة الالتحاق بالفرع المرغوب بهابه في المرحلة الثانوية استنادا على المهار ات التهات المختلفة.

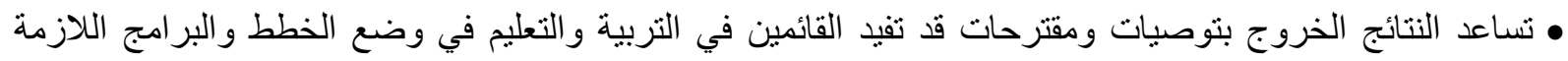

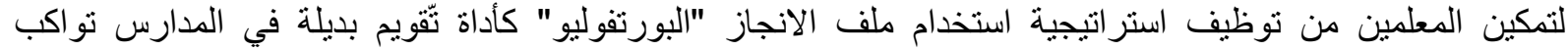
متطلبات العصر و التّربية المعاصرة التي تدعو إلى تربية إبداعية حو ارية وليس تربية تلقينيه بنكية.

حدود الآدراسة: الحدود الموضوعية: اتجاهات معلمي المرحلة الثانوية في القس الثرقية نحو توظيف ملف الانجاز "البورتفوليو" كأداة تقبّويم بديلة في التدريس. الحدود المكانية: اقتصرت الذّر الدّراسة على الددارس الثانوية الحكومية في مدينة القدس الثرقية.

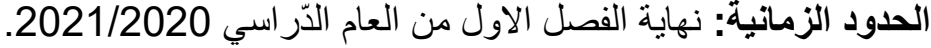

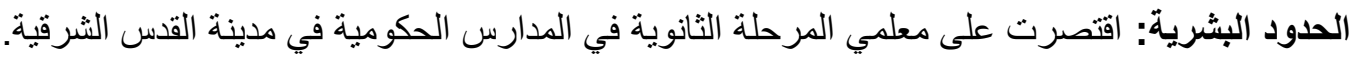

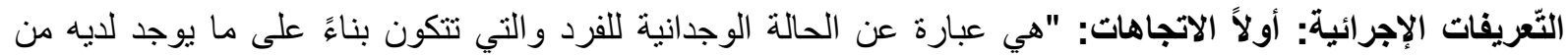

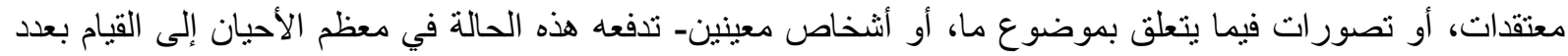

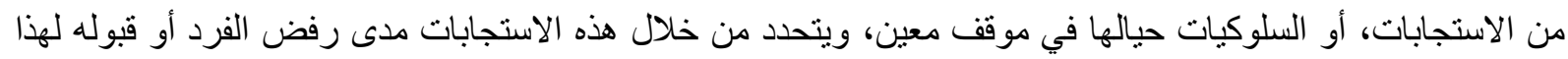

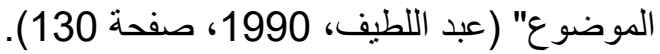
ويعرف الاتجاه إجر ائياً بأنه محصلة استجابات معلمي المرحلة الثانوية في مدارس القدس الثرقية الثانية نحو توظيف استر اتيجية

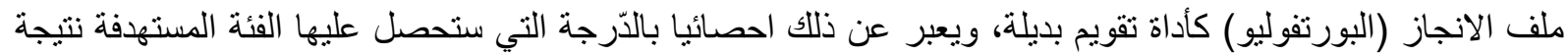

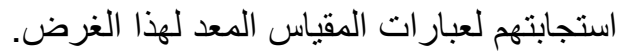
ثانياً ملف الانجاز "البورتفوليو": ملف الانجاز "البورتنفوليو "عبارة عن جمع منظم وغير عشوائي وهادف لأعمال

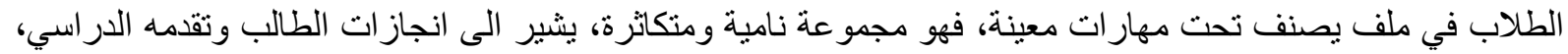

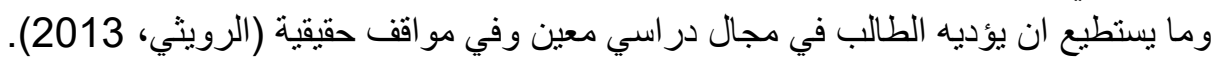

ويعرف ملف الانجاز اجر ائيا بأنه مجموعة من المهام التي نفذها الطالب في مباحث مختلفة في المرحلة الثنانوية.

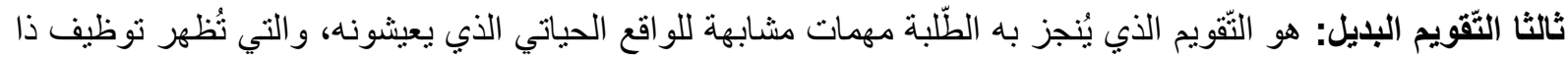

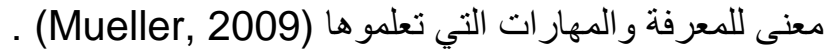

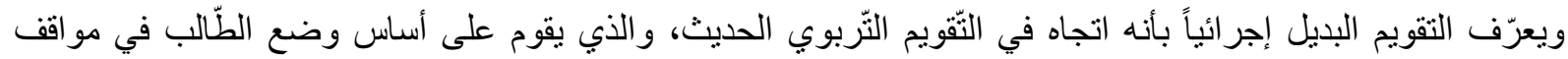

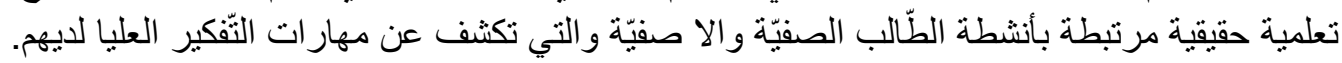

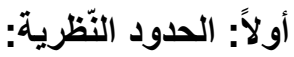

تعتبر فكرة ملف الانجاز (البورتفوليو) إحدى الطرق البديلة والهامة لعملية تقويم الطالب، حيث انتشرت خلال النال العقد الأخير في عدة دول عالمية مثل أمريكا وبعض دول الحفى أوروبا. وقد جاءت كردة فعل للطرق التقليدية المألوفة مثل 
الامتحانات المبنية وانطباعات المعلم الذاتية التي تهمِّش دور الطالب دون اعتبار له، مما يمنعه من المشاركة الفعّالة في عملية تقدمه. إن عملية بناء وتنفيذ الملف التي يتحمل مسئوليتها الطالب، تدمجه بشكل مباشر ودائم في عملية مر اقبة تقدمه، ونرسيّخ دور

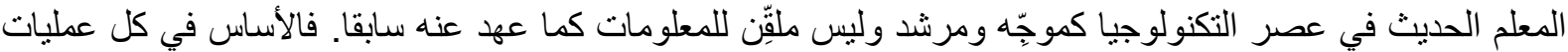
توثيق التقدم الذاتي، هو قلب دور الطالب من متعلم سلبي لشريك فعّال في عملية تقييمه لنفسه، تعزيز نظرته اتجاه قدر اته، وبالتالي توسيع آفاقه إلى أقصى الإمكانيات في عدة اتجاهات تربوية بناءة، تتمي شخصيته ونرفع من مستو اه الأكاديمي. إنّ البورتفوليو يشبه كرة التلج، التي تبدأ صغيرة الحجم، ثم سرعان ما تتحول إلى كرة كبيرة، وتغدو مشرو عاً يبدع في تشكيل هيئتها وتصميم شكلها كل من الصغار والكبار . ويضيفون إليها ما يشاءون من لمسات فنية مميزة، لتصير دمية يستمتعون بها. و هكذا البورتفوليو، الذي يبدأ بأول تقرير أو تحضير لخطة درس، وبالتدريج يكبر ليصير مشرو عا مميز ا، يعكس شخصية الطالب الذي يضع بصماته على جميع أجزائه؛ ولكن ما يميزه عن كرة الثلج التي تتكون وتختفي بوقت قصير، أنه يستغرق الكثير من الجهد و الابتكار حتى يكتمل؛ لذا فهو بترك آثناره ليدوم فترات طويلة

.(McLaughlin \& Lewes, 1994)

مفهوم ملف الانجاز (Portfolio):

ملف الانجاز (بورتفوليو) عبارة عن جمع يحتوي على نوثيث وتجميع هادفين، لنماذج تمثل أعمال أو مهارات أو أفكار

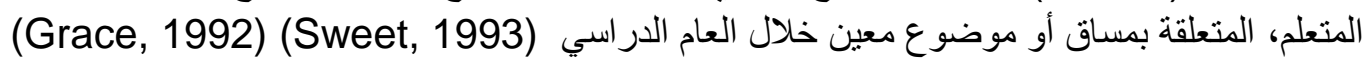
وقد يحتوي على توثيق لأفضل أعمال الطالب، أو بعض المهار ات التي ما زال

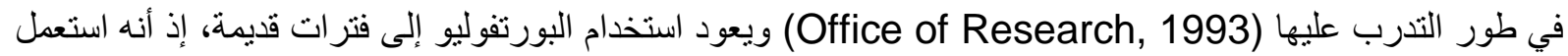

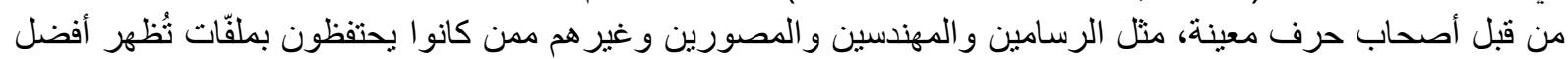

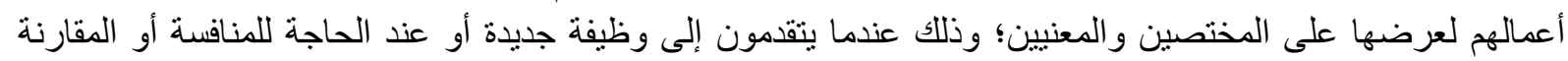

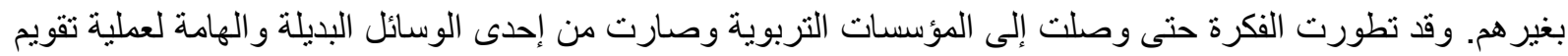

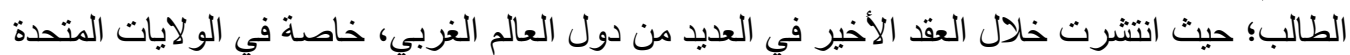

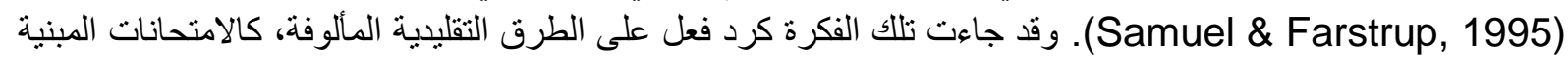

و انطباعات المعلم الذاتية (Sweet, 1993).

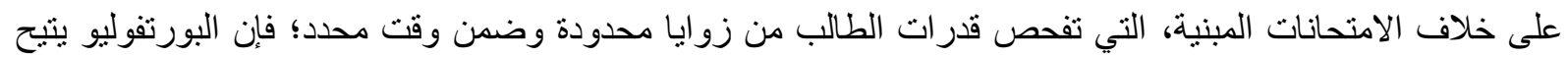

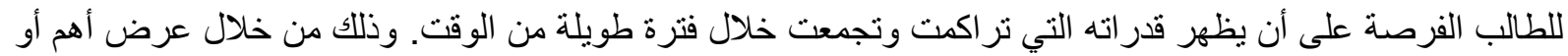

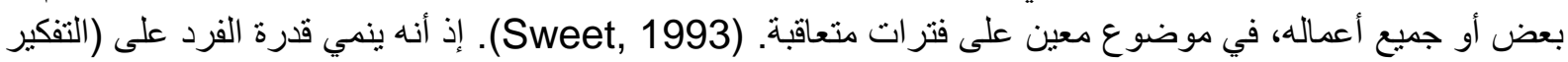

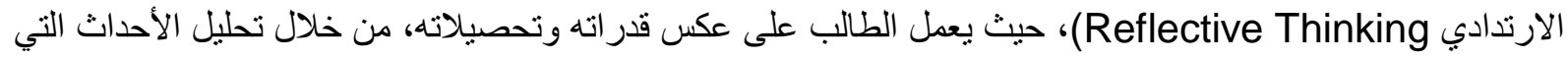

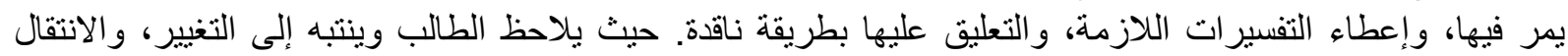

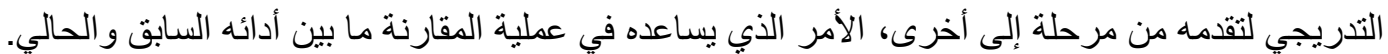

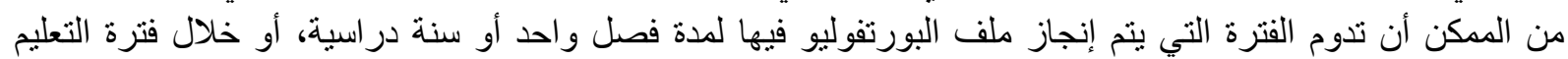

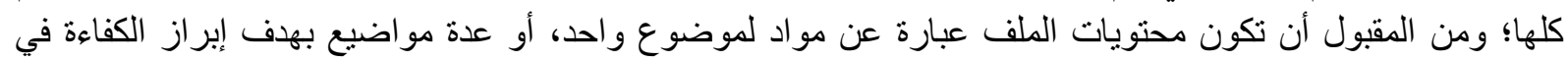

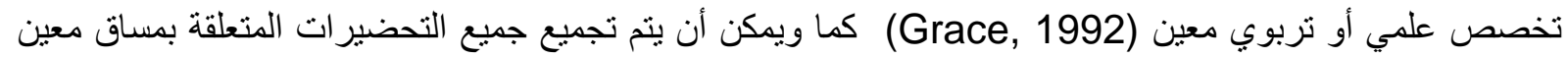

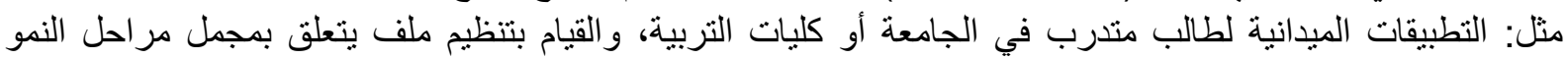

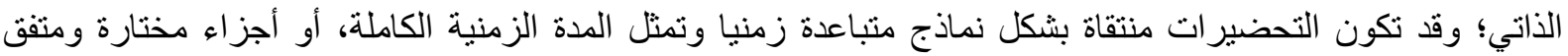

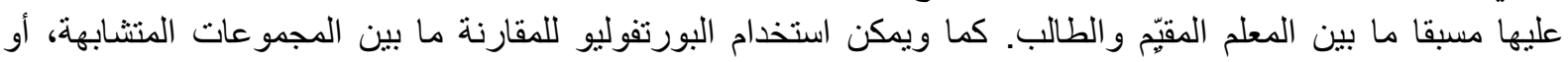

الصفوف أو المدارس (Sweet, 1993).

أهداف استعمال ملف الانجاز (البورتفوليو): لملف الانجاز أهداف تشمل الطالب، المعلم، ولي الأمر، و المشرفون و المتابعون.

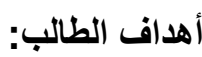

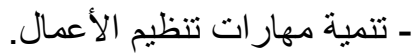




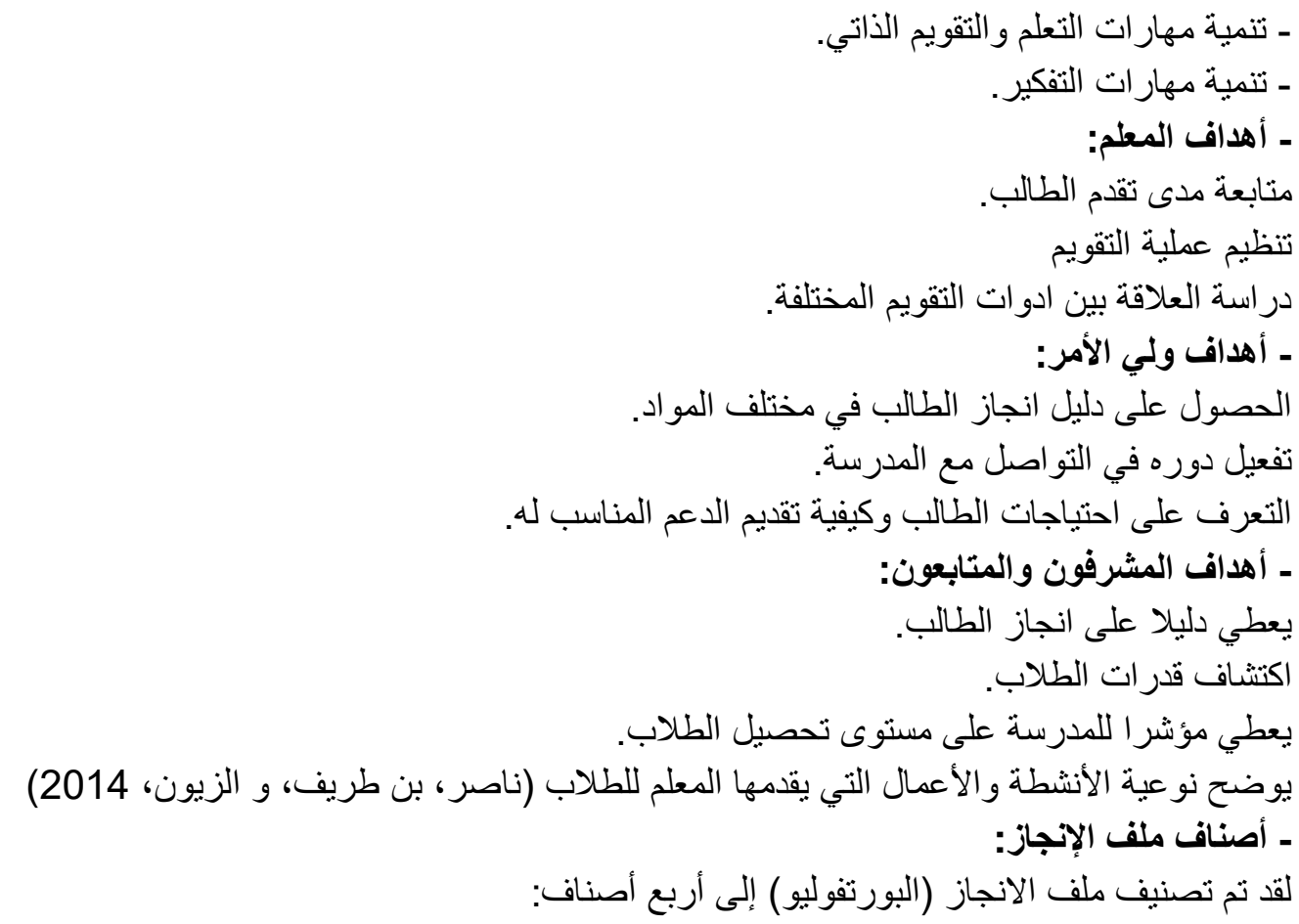

ـ الملف التجميعي (Dossier Portfolio): وفيه يتم تسجيل لأعمال أو تحصيل الطالب لأغر اض الاختيار أو الترقية

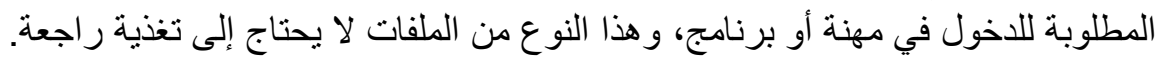
ـ ملف الطالب التّريبي (Training Portfolio): يعتبر عينة ممثلة لعمل الطالب خلال مدة زمنية محددة. مجموعة

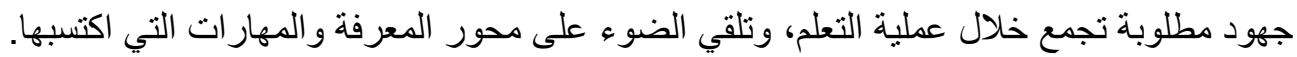

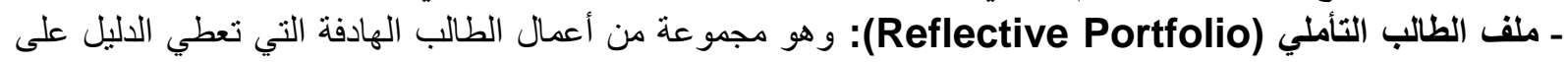
التقدم و النمو من خلال توليف تللك الأدلة لإظهار أفضل الممارسات المختارة والتي تناسب محكات تتو افق مع التقدم الذاتي

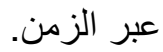
ـ ملف الطالب التطوري الثخصي (Personal Development Portfolio): وهو مجي مجمو عة من أعمال الطالب

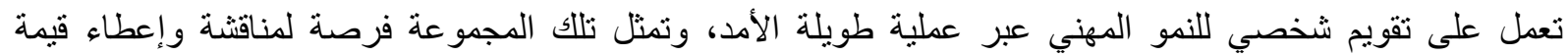

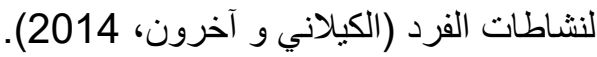
أنواع ملف الانجاز: 1 ملف الانجاز التقليدي هو عبارة عن ملف يتم تخصيصه من أجل تجميع أعمال الطالب، ويتم اختيار تلك الأعمال المجمعة

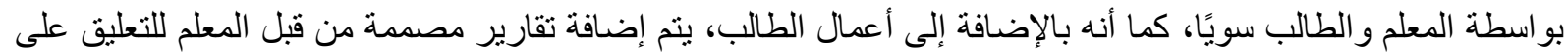

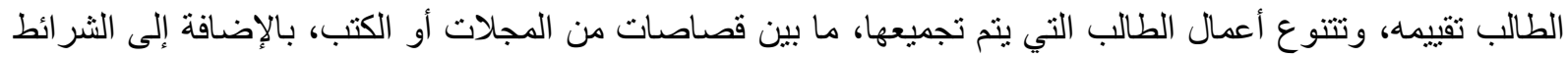
الصوتية، أو شر ائط الفيديو. ولكن يرى الكثير أنه يوجد سلبيات مختلفة في ملف الإنجاز التقليدي، وأهم تللك السلبيات هي صعوبة التحكم في المحتوى

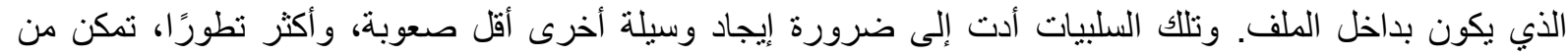
تجميع أعمال الطالب، وأن تكون تللك الوسيلة تكنولوجية، ومو الكبة الكية للعصر.

$$
\text { 2) ملف الإنجاز الإلكتروني: }
$$

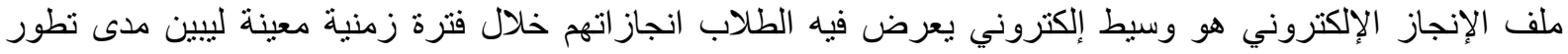

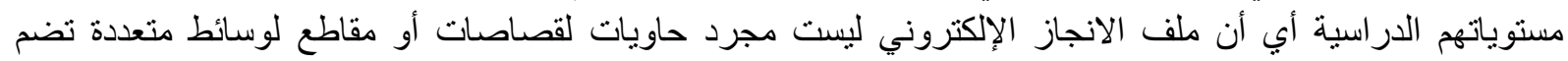

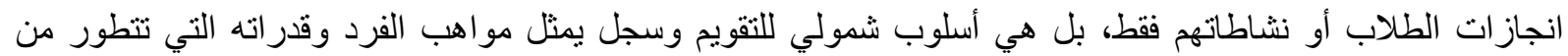
خلال سياقات مكانية وزمنية معينة. 
ميزات ملف الإنجاز الاكتروني:

- ينمي مهار ات الطالب في استخدام مهار ات التكنولوجيا.

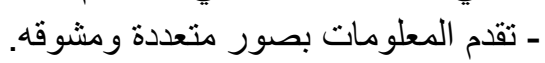

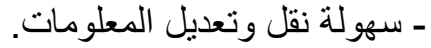
- يساهم في توفير الوقت و والجهد. - يوفر تغذية راجعه عن إنجاز اتوفيز الطالب للمعلم و المدرسة وولي الامر. ـ - اظهار مو اهب الطالب وتعزيز ها. - سهولة الوصول الى المر اجع (نصار و اللوح، 2017).

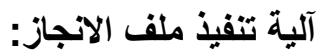

- يُحفظ هذا الملف في الغرفة الصّّفية مع تحديد ملف واحد لكل طالب.

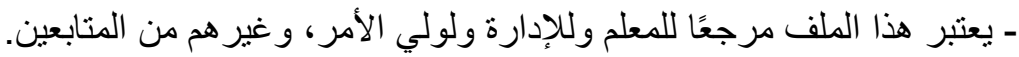

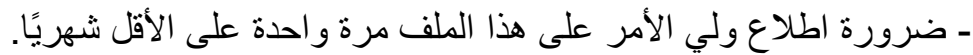

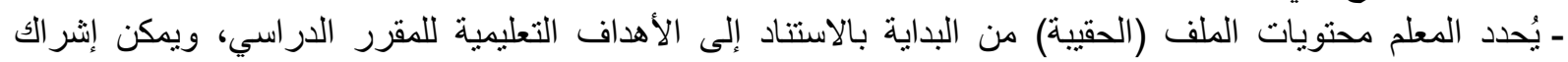
الطلاب في تحديد المحتويات. - يخصص لكل طالب حقيبة شاملة تضم إنجاز اته في المقرر الدراسي تفصل بينها فواصل.

محتوى ملف الانجاز (البورتفوليو):

ان ملف الانجاز ليس مجرد تجميع لبعض التعيينات، و المشروعات، و الصور، و التمارين التي برى الطالب انها يمكن ان

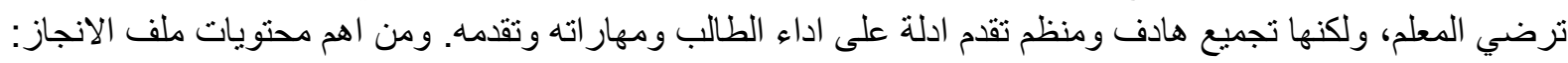

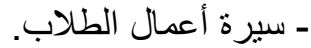

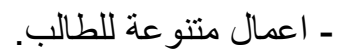

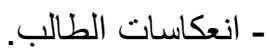

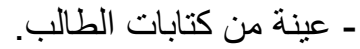
- قو ائم المصادر التي اطلع عليها الطالب و المواد التي استخدمها. - محائف التأمل الذاتي.

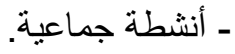
- صور ضونئية. - 2 - مو اد سمعية وبصرية.

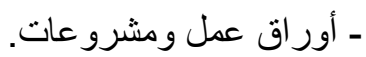
- درجات الاختبار ات التحصيلية وتقديرات وتقات أتقارير حول مشاهدات.

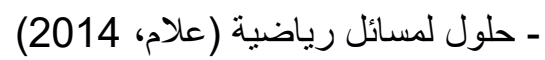
تقييم ملف الاتجاز:

يتطلب تقييم ملفات الانجاز اعداد محكات يستند اليها في الحكم على استخدام الطالب للمهارات و المعارف المرجوة، وكذللك

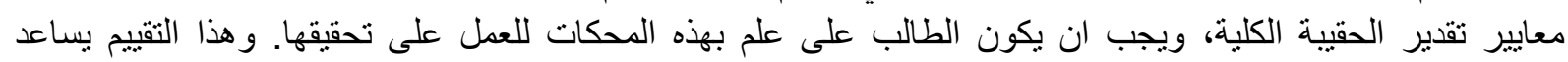
الطالب على التعرف على جوانب القوة والضعف في اعماله المتنو عة ويعمل على تقويمها (الفتلاوي، 2014)

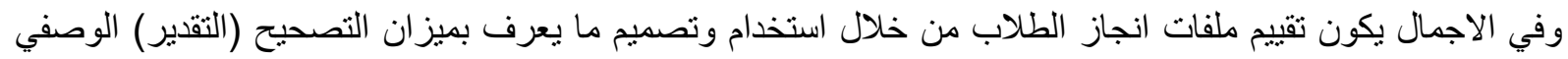

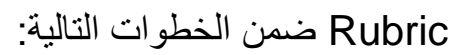
أولاً: تحديد المحكات و الجو انب والمهارات التي ستكون هي المر اد تقويمها وفقا لأهداف وموضوع ونون ونوع التقويم. ثانيا: تحديد مستويات الأداء المتوقع لكل جانب (محك) ثالثا: شرح وتوصيف المعايير المحققة لكل مستوى من المستويات في كل جانب او محك 
رابعا: تصميم ميزان وصفي ومتدرج للأداء Rubric على شكل جدول وتوضع فيه المحكات أو الجو انب المر اد قياسها

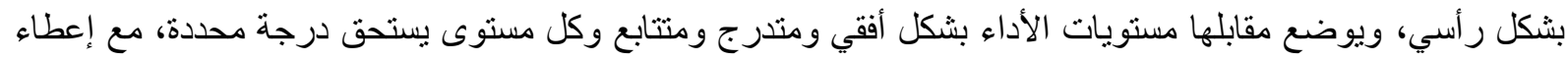
وصف مفصل لكل خانة من خانات المحكات (Smith \& Harm, 2003)

نبذة عن المدارس الثانوية في القدس الثرقية:

يبلغ عدد المدارس الثانوية الحكومية في القس الثرقية حوالي 27 مدرسة، منها ما هو خاص بالذكور، وأخرى خاصة

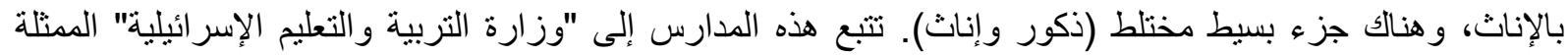

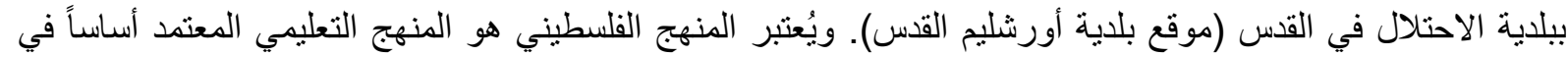

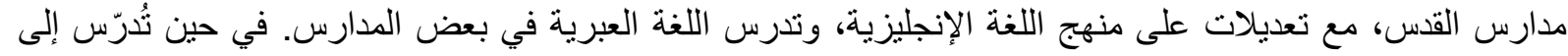

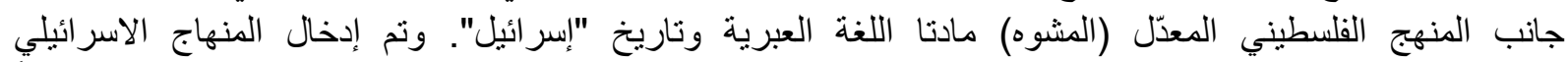

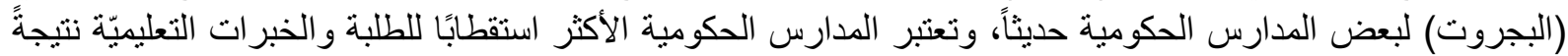
لتوفّر الميز انيّات وحريّة العمل والتوستع بعكس المدارس العربيّة الأخرى (موقع التعليم في مدينة القدس).

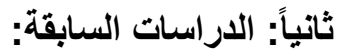

تناولت العديد من الدّر اسات موضوع التّقيم البديل و أدو اته المختلفة ومنها ملف الانجاز (البورتفوليو)، ففي دراسة أجراها

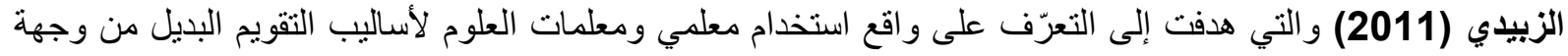

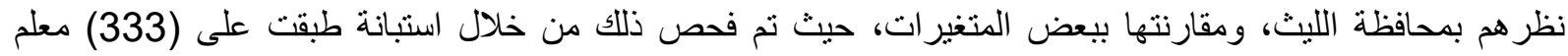
ومعلمة، واستخدم المنهج الوصفي للتحليل. بينت النتائج أن الاختبارات الكتابية حازت على التى المرتبة الأولى يليها التقويم

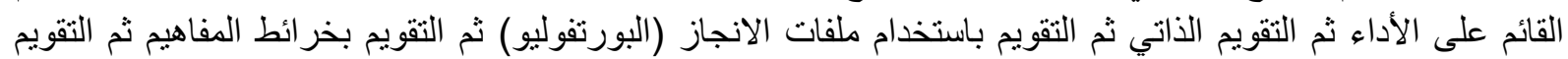
القائم على الملاحظة ثم تقويم الأقران. كما وأظهرت النتائج وجود فروق دالة فالة الحصائيا بين آراء معلمي ومعلمات العلوم

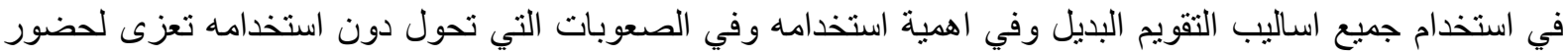

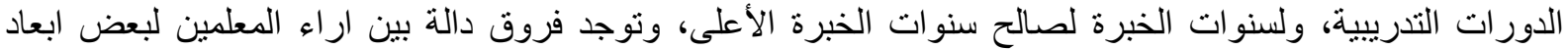

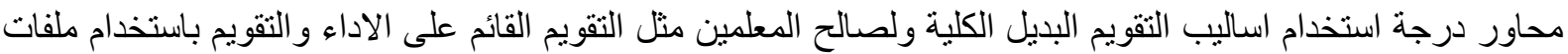

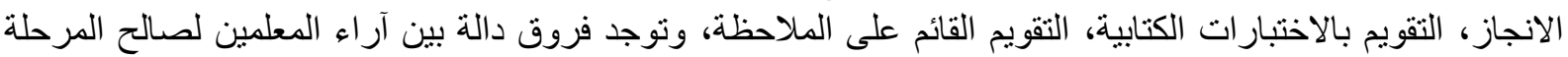

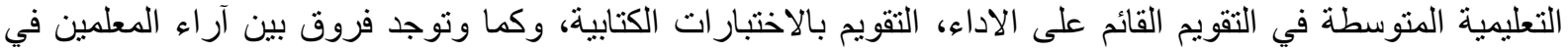

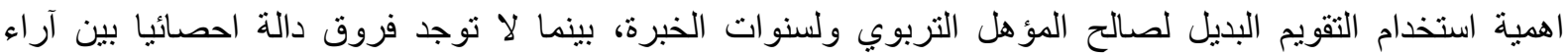

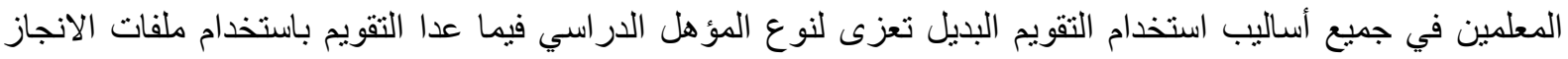

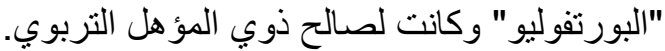

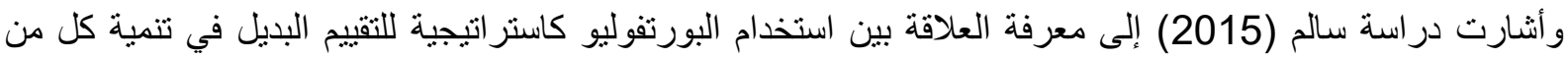
التفكير التأملي و أداء طلاب المرحلة الجامعية في جامعة المنوفية، وتكونت عينة البحث من (150) طالبا وطالبة بكلية

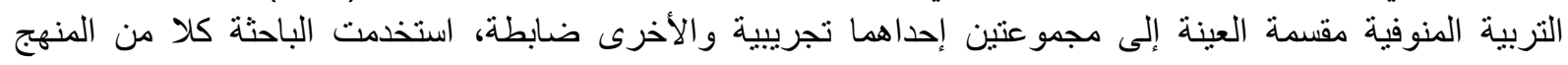

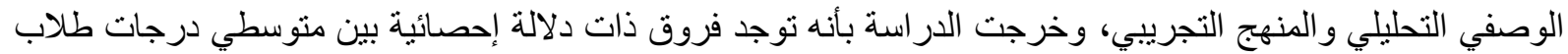

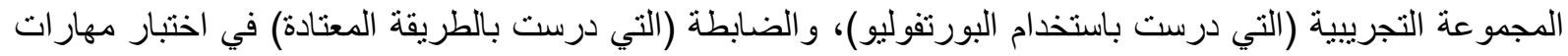

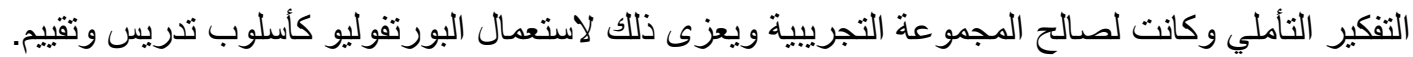

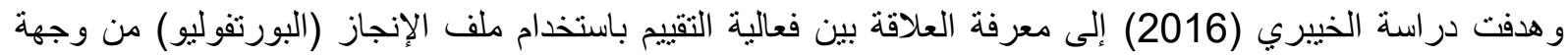

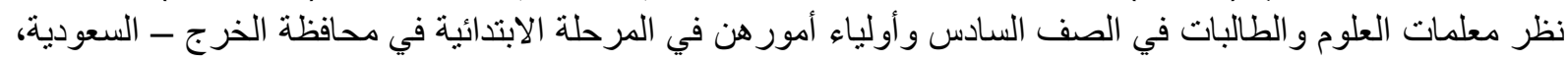

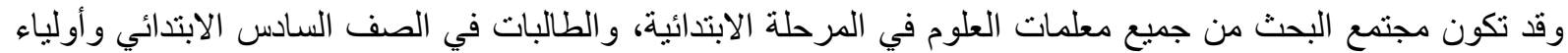

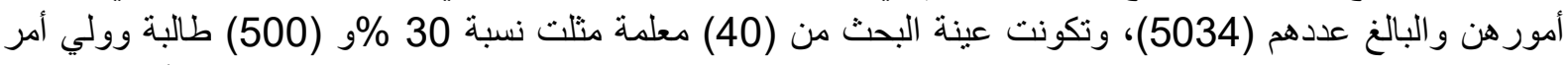
يمثلون نسبة (10\%) من مجتمع الدراسة، وقد استخدمت الباحثة المنهج الوصفي التحليلي و الاستبانة كأداة للدراسة، 
وخرجت الدراسة بمو افقة أولياء الأمور على فعالية التقييم باستخدام ملف الإنجاز. وموافقة الطالبات على فعالية التقييم

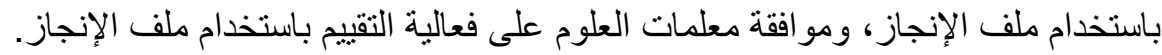
وأوضحت دراسة كيلبان و ميلمان (Kilbane \& Milman, 2017) معرفة العلاقة بين أثر استخدام ملف الإنجاز الرقمي كأداة تقييم في المدارس الثانوية على اتجاهات المعلمين من ناحية تدريسهر وتعلم الطلبة في أمريكا، وقد تكونت

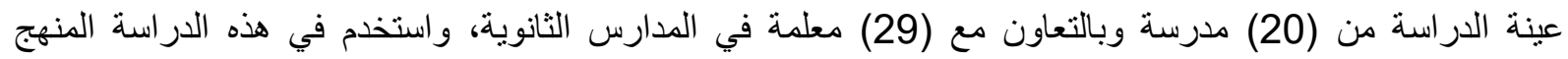

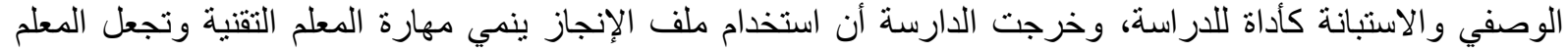

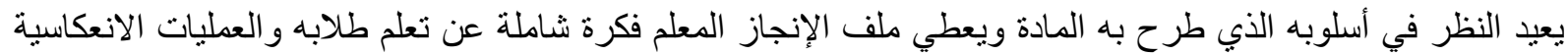
التعلمية و أهمية استخدام ملف الإنجاز كأداة ثقييم بديلة وحديثة. كما أكدت دراسة إزسي (Izci \& Caliskan, 2017) وكاليسكان معرفة العلاقة بين اتجاهات المعلمين ومدى (الإنى

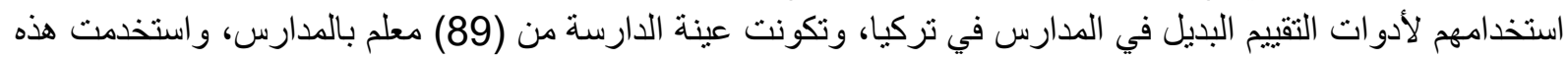

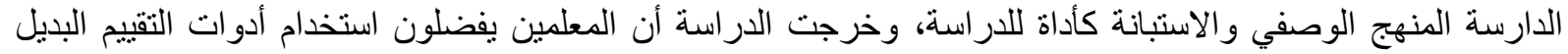

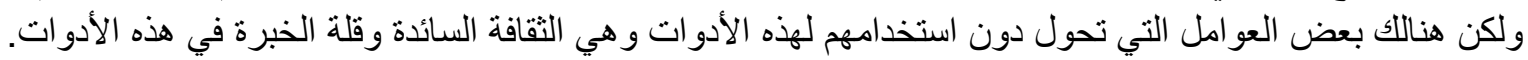

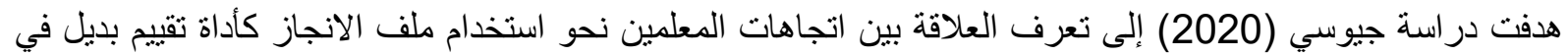

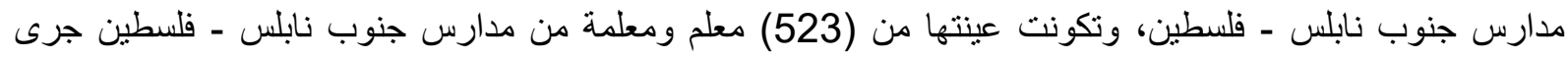

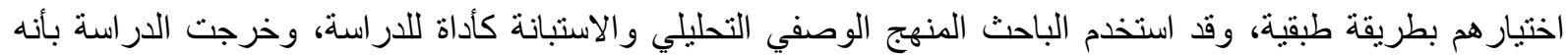

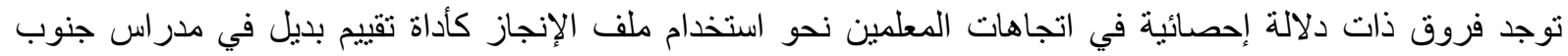

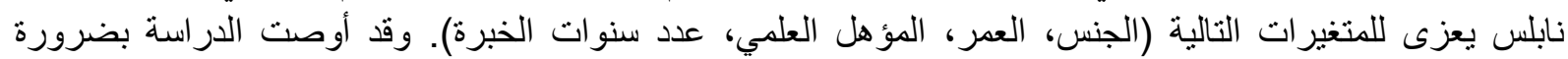

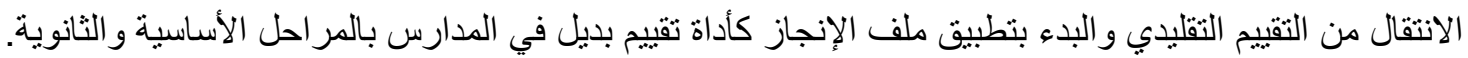

\section{التّّليق على الدّراسات السابقة وأهميتها للاراسة الحالية:}

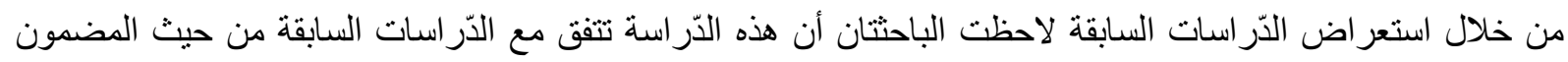

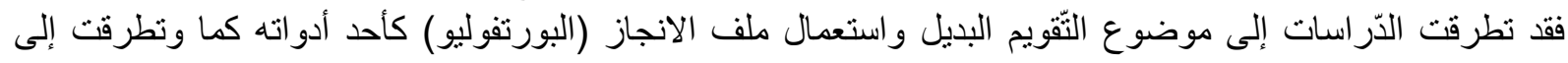
أهميته. و اختلفت عن الذّر اسات السابقة من حيث:

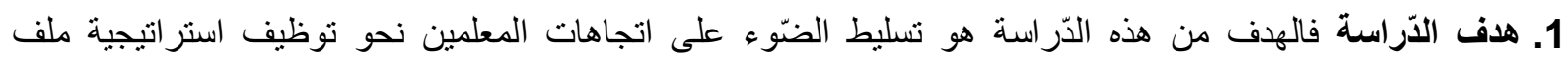
الانجاز (البورتفوليو) كأداة تقّويم بديلة. 2. خصوصية الوضع في الددارس الحكومية في القدس الثرقية والتي لانية تنشبه في واقعها المناطق الأخرى، وانعكاساتها التّربوية على عمليتي التعليم و التعلّم.

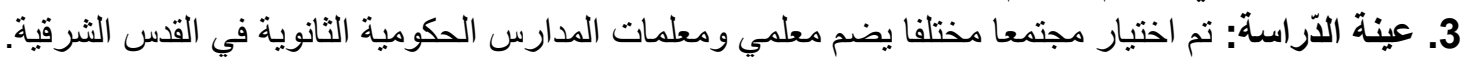

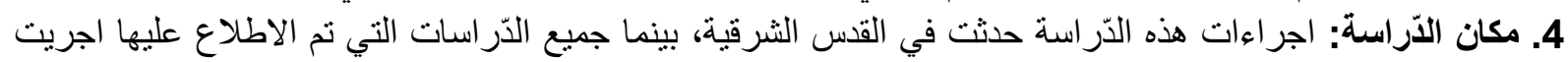

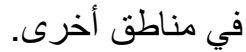
جانب إفادة الدّر اسة الحالية من الدّر اسات السابقة بالعديد من النّقاط منها:

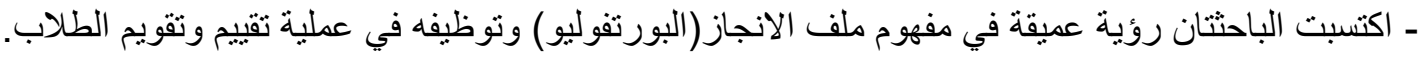

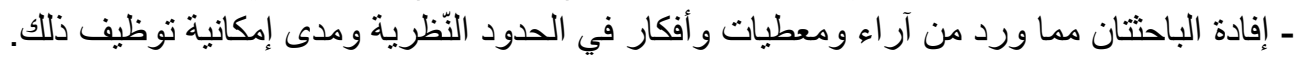

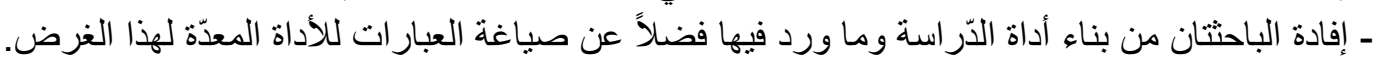

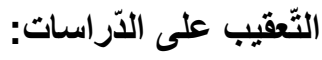

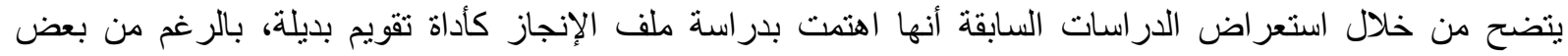

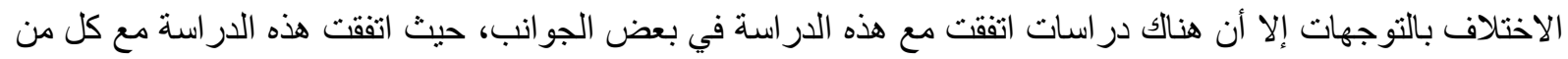

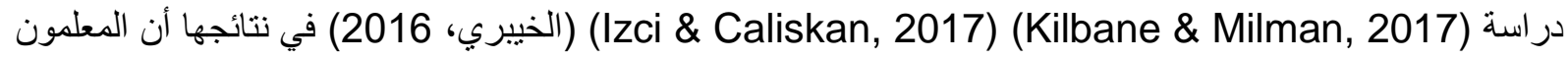

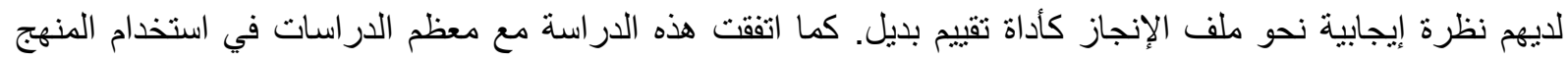

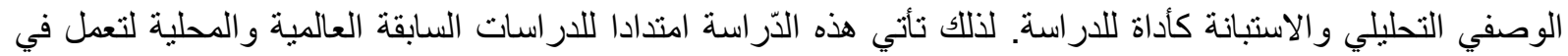

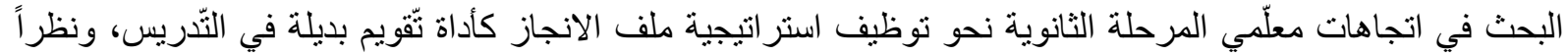
لندرة الدّراسات التي تنتاولت هذا الموضوع بمنطقة القدس الثرقية جاءت هذه الدّراسة للإضافة إلى الأدب التّربوي 
و العمل على إثرائه، و أيضاً لسد الثغرة نتيجة النّدرة في الذّراسات التي تتاولت هذا الجانب في مدارس القدس الحكومية،

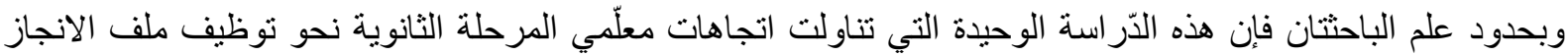
كأداة تقويم بديل في التّريس في منطقة القدس الثرقية.

$$
\text { منهجية وإجراءات الدّراسة: }
$$

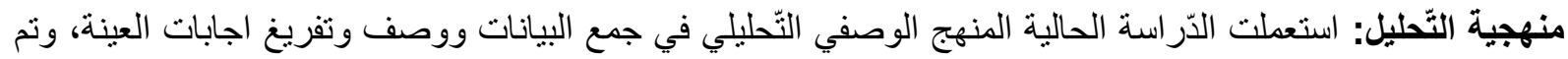

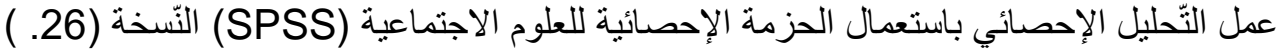

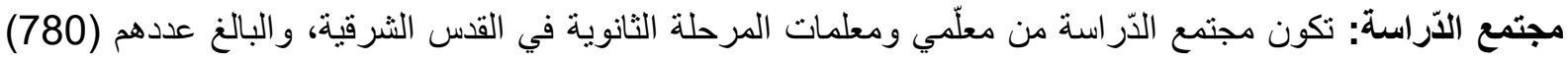
معلما ومعلمة موز عون على (27) مدرسة، في الفصل الدّراسي الأول للعام الدّر اسي

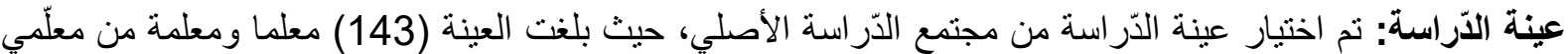

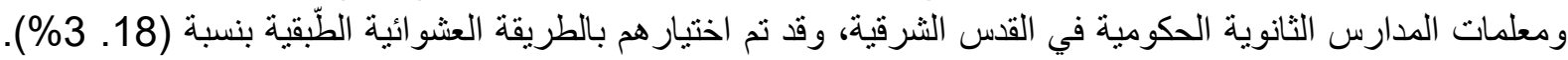

\begin{tabular}{|c|c|c|c|c|}
\hline النسبة المئوية\%\% & التّكرار & الفئة & المتغير & الرّقم \\
\hline 35.7 & 51 & معلم & \multirow{2}{*}{$\begin{array}{c}\text { النوع الاجتماعي الجندر } \\
\text { (معلم- معلمة) }\end{array}$} & \multirow[t]{2}{*}{1} \\
\hline 64.3 & 92 & معلمة & & \\
\hline 10.5 & 15 & أقل من 5 سنو ات & \multirow[t]{3}{*}{ عدد سنوات الخدمة } & \multirow[t]{3}{*}{2} \\
\hline 24.5 & 35 & أكثر من 5 و أقل من 10 & & \\
\hline 65.0 & 93 & 10 سنو ات فأكثر & & \\
\hline 27.3 & 39 & ل لغات & \multirow{4}{*}{ المادة التُعليمية التي يدرسها } & \multirow[t]{4}{*}{3} \\
\hline 20.3 & 29 & العلوم & & \\
\hline 17.5 & 25 & الرّياضيات & & \\
\hline 35.0 & 50 & أخرى & & \\
\hline 24.5 & 24.5 & صف العاثر & \multirow[t]{3}{*}{ الصف الذي تعلمه } & \multirow[t]{3}{*}{4} \\
\hline 28.0 & 28.0 & صف الحادي عشر & & \\
\hline 47.6 & 47.6 & صف الثاني عشر & & \\
\hline
\end{tabular}
كما موضح بالجدول (1) يبين توزيع عينة الدّر اسة على المتغير ات الدّيمغر افية ونسبها المئوية الفية:

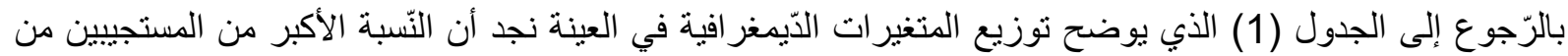

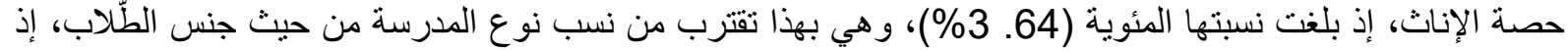

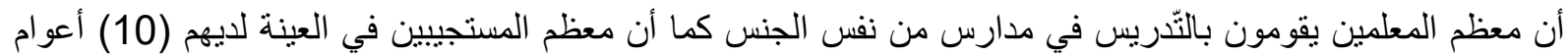

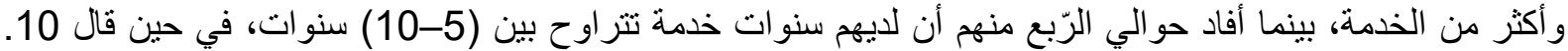
5\% فقط أنهم يمتلكون من الخدمة أقل من 5 أعوام، كما توزعت المواد التعاد التي يدرسها المستجييون بين اللغات بنسبة 27.

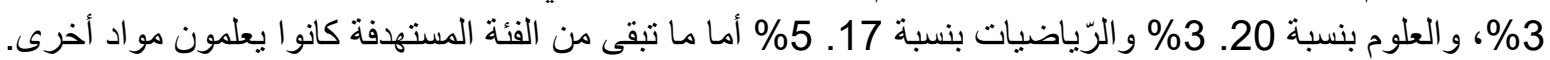

تم الرجوع إلى الأدب النظري من أجل اختيار فقرات الاستبانة، ونم الاستعانة باستبانة (الحجيلي، 2016) و التي بحثت الإنت

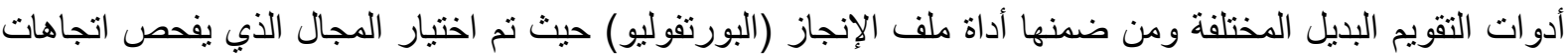

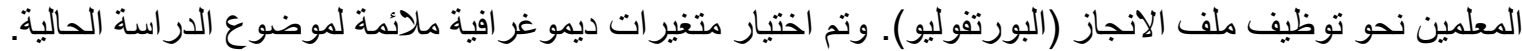

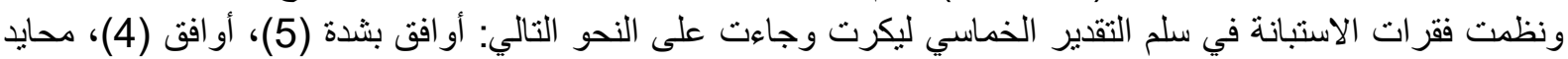

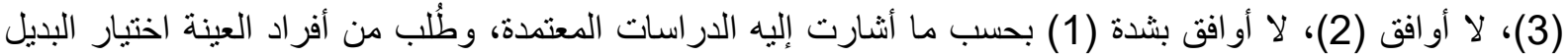

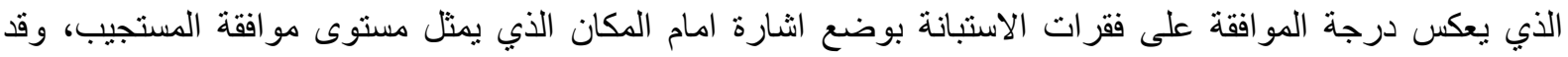


تكونت الاستبانة بصورتها النهائية من قسمين: القسم الأول يشمل معلومات ديمو غر افية عن المستجيب. القسم الثاني يشمل

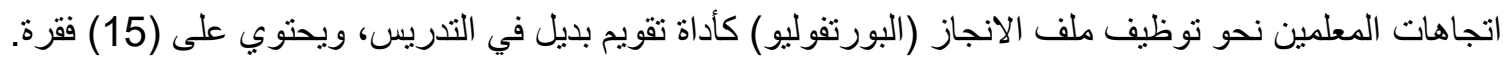

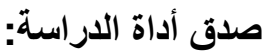
تم التّحقق من صدق الأداة بصورتها المُعدلة عن طريق عرضها على مجموعة من المحكمين ذوبي الاختصاص التُّبوي

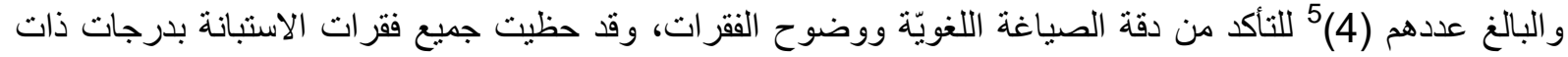

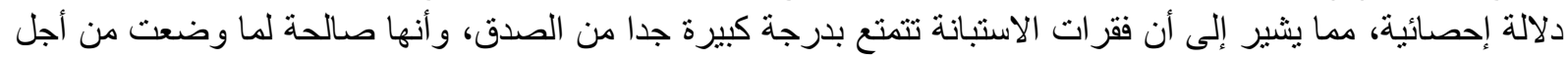

ثبات اداة الدراسة: تم التحقق من ثبات أداة الدر اسة بعرضها على عينة استطلاعية من خارج العينة بلغ عددها (26) باستخدام معادلة الثبات

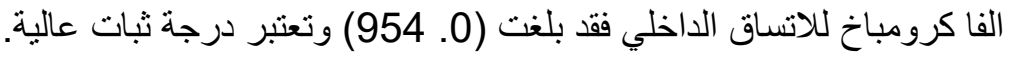

الوزن النّببي والمعالجات الإحصائية:

استخدمت الباحثنان مقياس ليكرت الخماسي، حيث تم ترميز الاجوبة من (1) إلى حيث (5) إلى إذ يمثل الرّقم (1) الإجابة

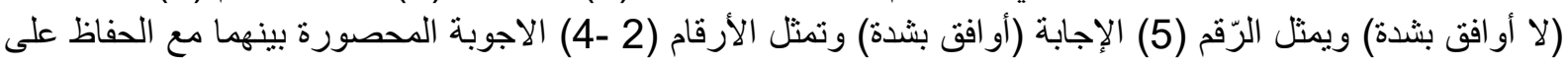

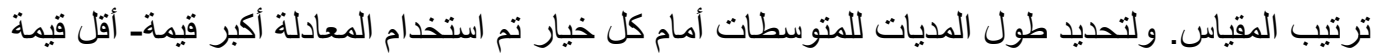

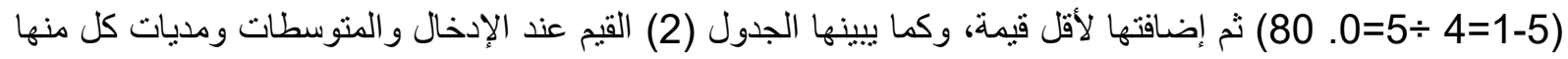
وتقدير الممارسة المقابلة لكل منها

\begin{tabular}{|c|c|c|c|c|}
\hline تقدير الاستجابة & مديات المتوسطات & القيم عند الإدخال & خيارات الإجابة & \\
\hline بدرجة ضعيفة جدا & $80.1-1$ & 1 & أو افق بشدة & 1 \\
\hline بدرجة ضعيفة & $60.2-81.1$ & 2 & أو افق & 2 \\
\hline بدرجة متوسطة & $40.3-61.2$ & 3 & محايد & 3 \\
\hline بدرجة عالية & $20.4-41.3$ & 4 & لا أو افق & 4 \\
\hline بدرجة عالية جدا & $5-4.21$ & 5 & لا أو افق بشدة & 5 \\
\hline
\end{tabular}

المعالجات الإحصائية المستخدمة في الآراسة:

تم استعمال البرنامج (SPSS) للمعالجات الإحصائية ومنها: المتوسطات الحسابية والانحر افات المعيارية للإحصاء

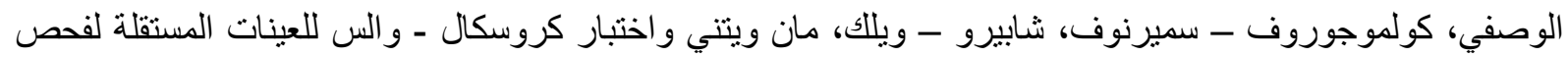
الفرضيات.

مناقثة وتحليل نتائج الآدراسة:

بهدف الاجابة عن سؤال الدراسة استخرج المتوسط الحسابي والانحر اف المعياري توضح كل من القيم الصغرى و القيم العظمى بالإضافة إلى مؤشر اتجاهات المعلمين نحو استعمال ملف الانجات الانجاز (البورتفوليو) كأداة تقييم بديل. تم ترميز درجات القبول على هذه البنود كالتالي:

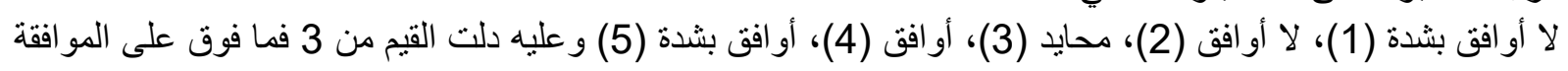
و القيم من 2 فما أقل على عدم الموافقة. لافئ.

5 أ. م. د خالد أبو عصبة، علم الاجتماع التربوي، الجامعة العربية الامريكية، فلسطين التربين

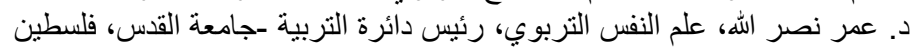

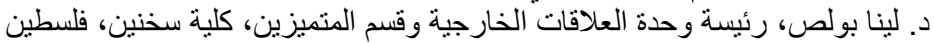

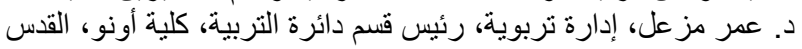




\begin{tabular}{|c|c|c|}
\hline عدد فقرات المجال & 15 \\
\hline 0.77 & 3.40 & المتوسط الحسابي 15 \\
\hline
\end{tabular}

يبين جدول (3) المتوسط الحسابي و الانحر اف المعياري حيث تجاوز منوسط الإجابة القيمة 3 مما يعني أن هناك ميل عام

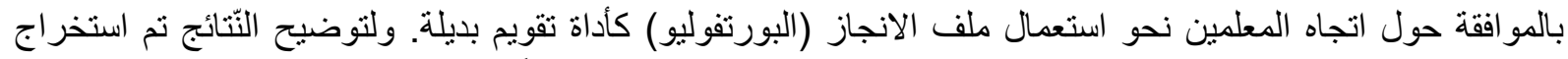

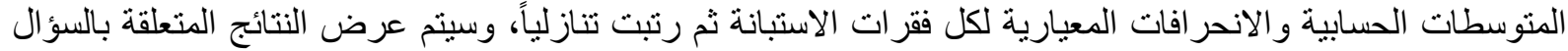

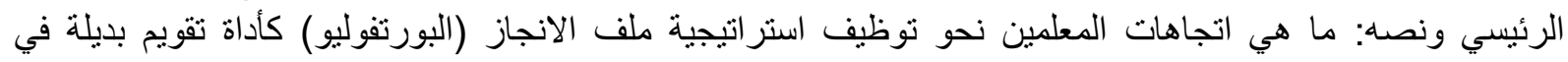

التدريس؟ (التبسئ الجدول (4) اتجاهات المعلمين نحو توظيف ملف الانجاز (البورتفوليو) كأداة تقويم بديلة في التدريس

\begin{tabular}{|c|c|c|c|c|c|}
\hline 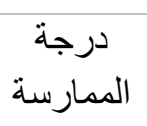 & 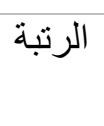 & 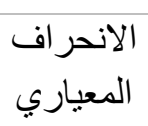 & الحسابي - الوسط & 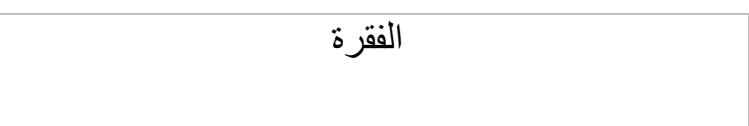 & 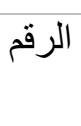 \\
\hline عالية & 1 & 0.94 & 3.66 & مشاركة الطلاب في أنشطة ملف الإنجاز يزيد من & 1 \\
\hline عالية & 2 & 0.83 & 3.62 & مشاركة الطلاب في أنشطة ملف الإنجاز يساعدهم على الابتكار وإبر از مو هبتهم & 2 \\
\hline عالية & 3 & 0.97 & 3.59 & أنشطة ملف الإنجاز تتيح للطلاب فرصة للبحث & 4 \\
\hline عالية & 4 & 0.95 & 3.57 & ملف الإنجاز يجعل الطلاب يركزون على إنجازات & 7 \\
\hline عالية & 5 & 0.94 & 3.52 & العمل في ملف الإنجاز يجعل الطلاب يعتمدون على في تعلى & 5 \\
\hline عالية & 6 & 0.95 & 3.45 & العمل في ملف الإنجاز يُتيح للطلاب الفرصة لتقييم & 9 \\
\hline عالية & 7 & 0.93 & 3. 43 & يُساعد ملف الإنجاز في تشخيص نواحي القوة و الضعف ألفاء الطلاب & 10 \\
\hline عالية & 8 & 1.03 & 3. 42 & العمل في ملف الإنجاز يزيد العبء الدر اسي على & 12 \\
\hline عالية & 9 & 0.97 & 3. 41 & يُشجع العمل في ملف الإنجاز على تفاعل الطلاب مع & 15 \\
\hline منوسطة & 10 & 0.95 & 3.37 & أرى أن ملف الإنجاز بِاعد على علاج صعوبات التعلّم & 3 \\
\hline منوسطة & 11 & 1. 02 & 3. 31 & يُحقِق تقييم ملف الإنجاز حكم حقيقي على أداء الطلاب & 6 \\
\hline متوسطة & 12 & 1. 04 & 3.25 & العمل في ملف الإنجاز يُشجع الطلاب على الانضباط المداط & 11 \\
\hline منوسطة & 13 & 0.99 & 3. 22 & ملف الإنجاز يجعل الطلاب يهتمون بالأنشطة ويغفلون & 8 \\
\hline متوسطة & 14 & 1. 13 & 3. 19 & العمل في ملف الإنجاز يؤدى إلى انخفاض نسبة غياب & 13 \\
\hline متوسطة & 15 & 1.06 & 3. 03 & يُقلل ملف الإنجاز من احتياج الطلاب للاروس الخصوصية & 14 \\
\hline
\end{tabular}




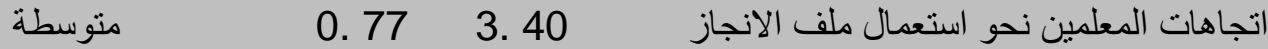

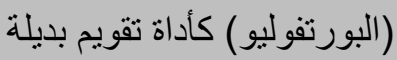

يتضح من الجدول (4) الردود فيما يخص اتجاهات المعلمين نحو توظيف ملف الانجاز (البورتفوليو) كأداة تقويم بديلة،

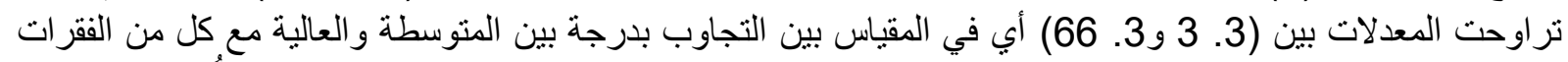

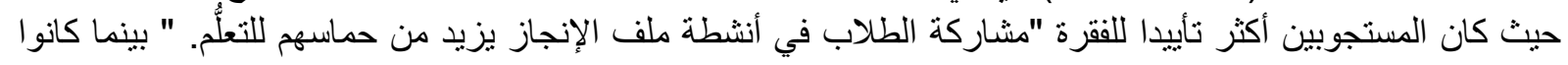

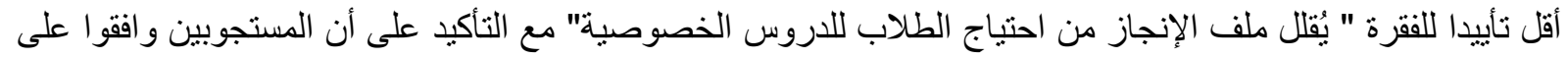

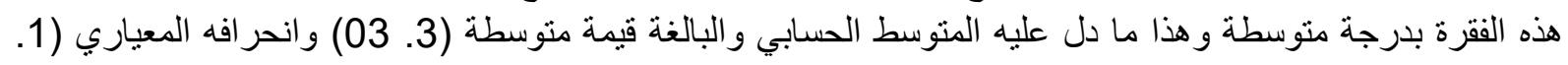

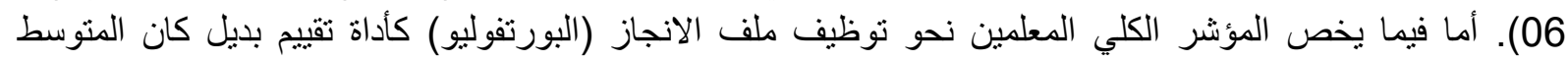

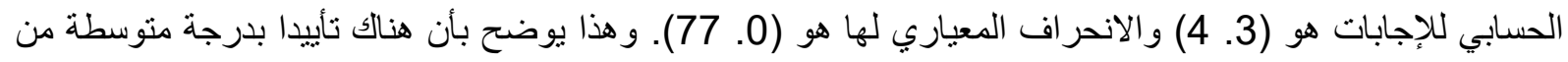
قبل معلمي المرحلة الثنانوية نحو توظيف ملف الانجان الأفراز (البورتفوليو ) كأداة تقويم بديلة.

وللتحقق من الهُف الرّئيس يتطلب الإجابة على الفرضيات الآتية:

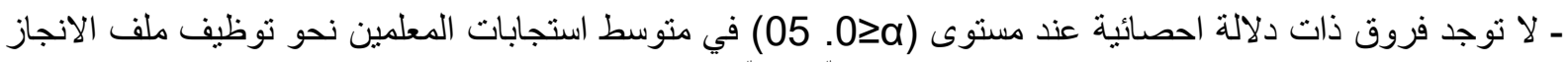
(Portfolio)

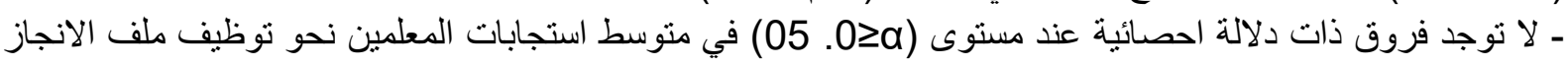
تعزى لمتغير سنوات الخدمة.

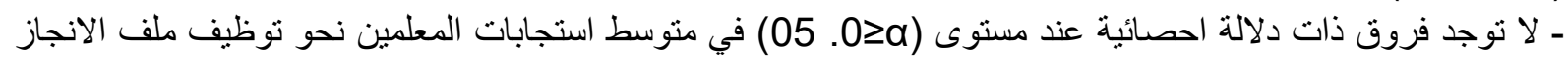
تعزى لمتغير المادة التعليمية.

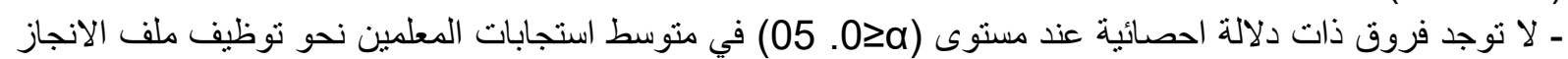
(Portfolio)

للتمكن من اختبار الفرضيات تم فحص توزيع المتغير ليتم اختبار الاختبار ات بناء على هذا التوزئ لتوزيع.

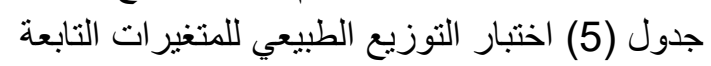

\begin{tabular}{|c|c|c|c|c|c|c|}
\hline \multicolumn{7}{|c|}{ اختبار التوزيع الطبيعي } \\
\hline \multicolumn{3}{|c|}{ شابيرو - ويلك } & \multicolumn{3}{|c|}{ كولموجوروف - سميرنوف } & \\
\hline القيمة & درجة & قيمة & القيمة & درجة & قيمة & \\
\hline الاحتمالية & الحرية & الاختبار & الاحتمالية & الحرية & الاختبار & \\
\hline 0000 & 143 & 0.958 & 0.001 & 143 & .105 & 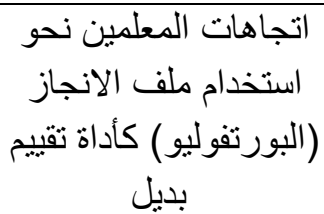 \\
\hline & & & & & كالية & a تعديل ليليفورس للقيمة \\
\hline
\end{tabular}

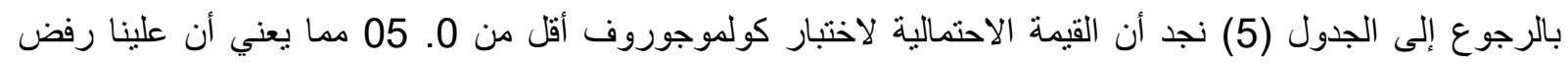

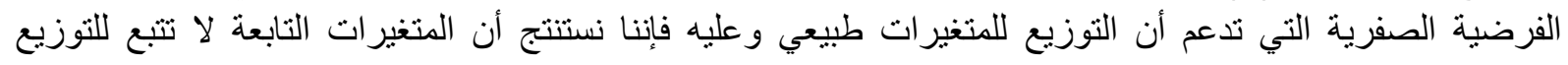

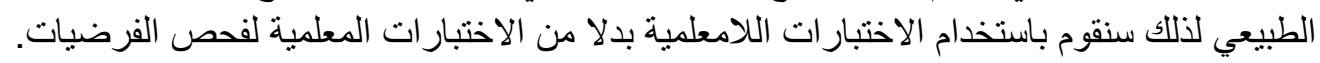

\section{نتائج الفرضية الرّئيسة:}

الجدول (6) نتائج الاختبار ات اللامعلمية (اختبار مان ويتني واختبار كروسكال - و الس) لفحص وجود فرون فروق ذات دات دلالة

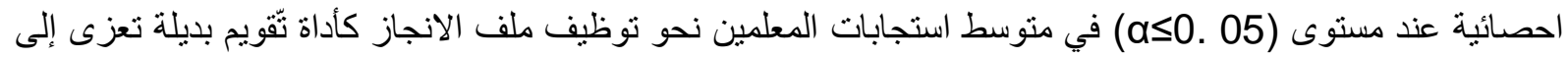

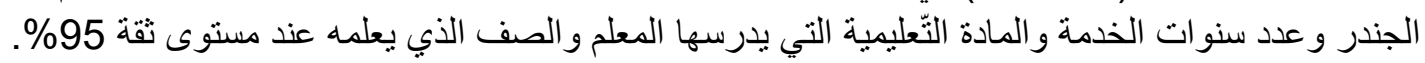




\begin{tabular}{|c|c|c|c|c|c|c|}
\hline \multicolumn{7}{|c|}{ ملخص اختبار الفرضيات } \\
\hline & الاحتمالبة & الحرجية & الاختبار & الاختبار & الفرضية الصفرية & \\
\hline 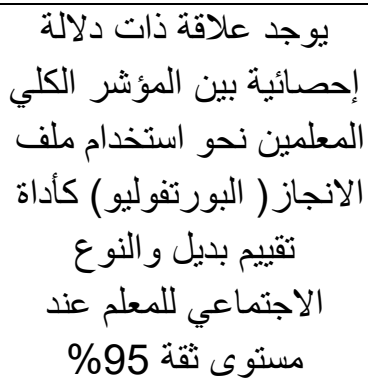 & $<0.001$ & & $\begin{array}{c}1398 \\
5\end{array}$ & للعينات اختبار & 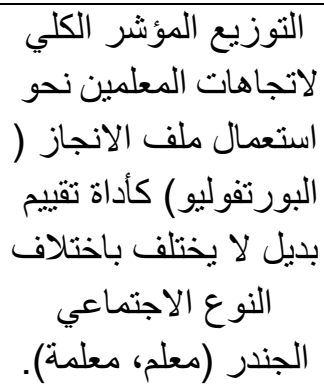 & 1 \\
\hline 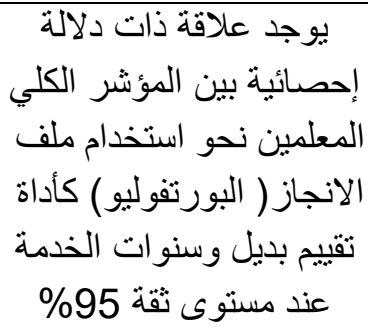 & $<0.001$ & 2 & $\begin{array}{l}.39 \\
160\end{array}$ & كروسكال & 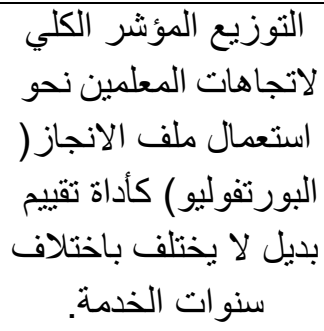 & 2 \\
\hline 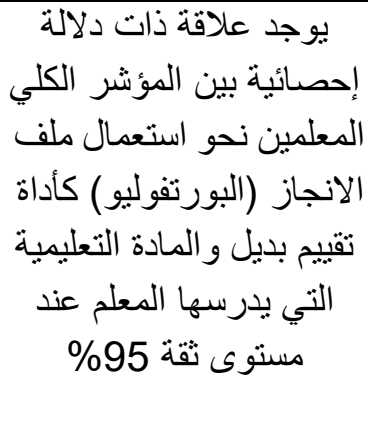 & 0.022 & 3 & 9.659 & كروسكال - اختبار & لالاتجاهات المعلمين المؤشر الكلي & 3 \\
\hline 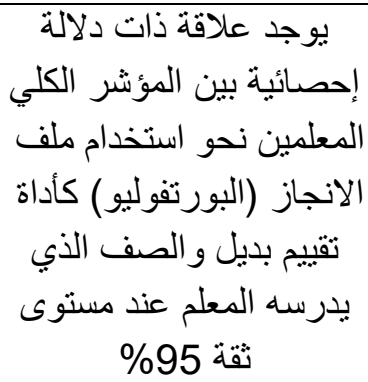 & $<0.001$ & 2 & $\begin{array}{l}.27 \\
272\end{array}$ & كروسكال & 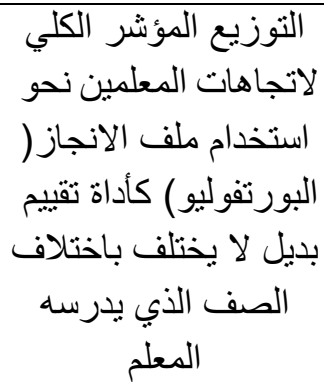 & 4 \\
\hline
\end{tabular}

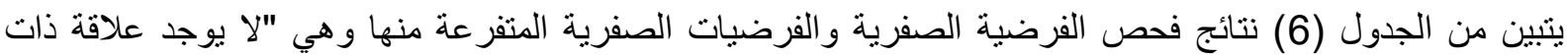
دلالة إحصائية عند مستوى (650.05) في منوسط استجابات المعلمين نحو استخدام ملف الانجاز (البورتفوليو) كأداة

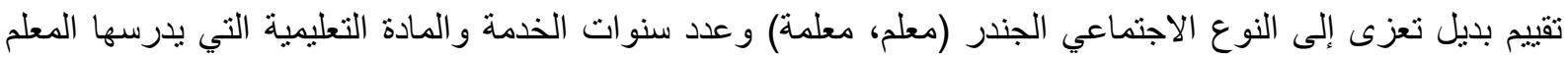

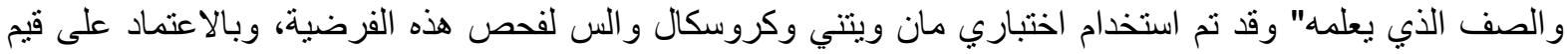

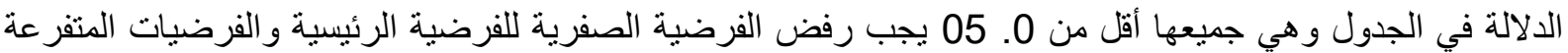

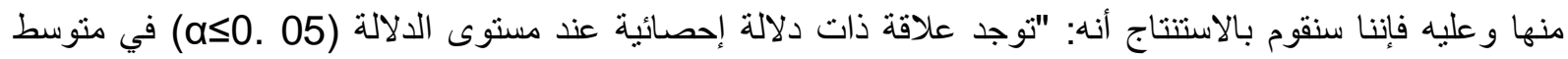

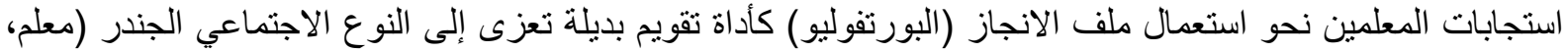

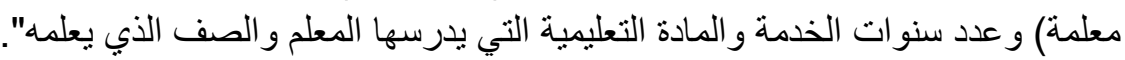


"ما اتجاهات معلمي المرحلة الثانوية بمدارس القدس الثرقية نحو نوظيف ملف الانجاز(البورتفوليو) كأداة تُّويم بديل في

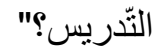

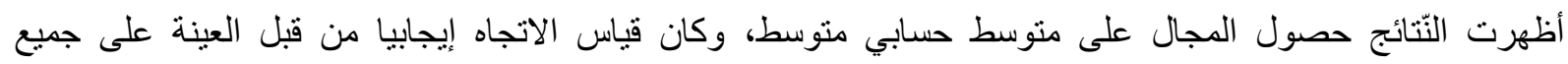

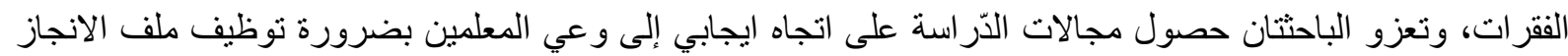

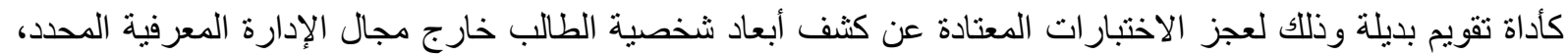

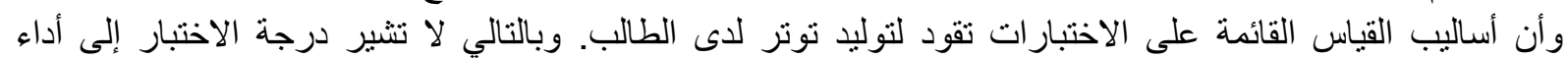

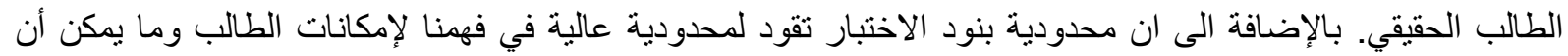

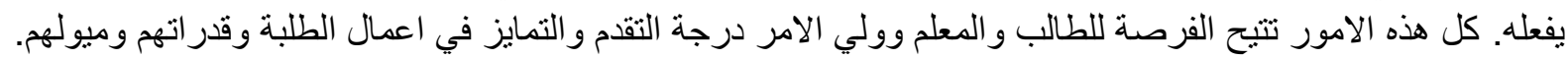

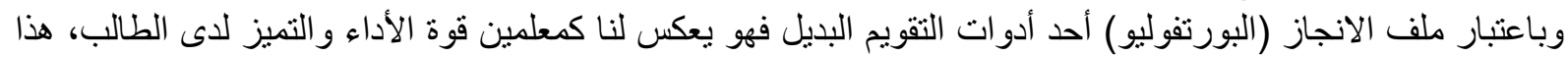

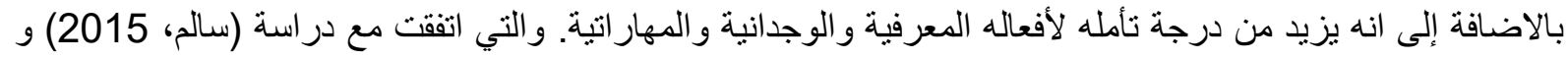

(Kilbane \& Milman, 2017)

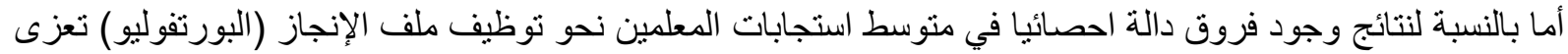

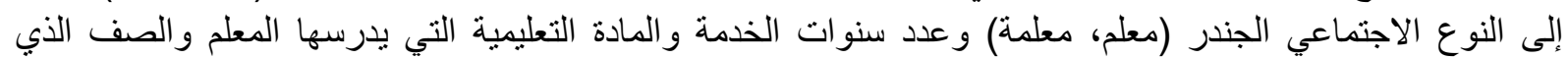

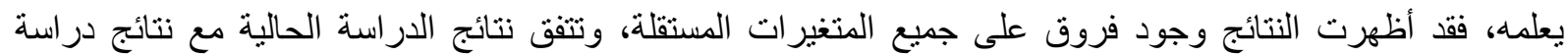

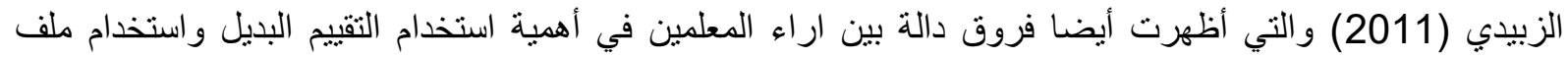

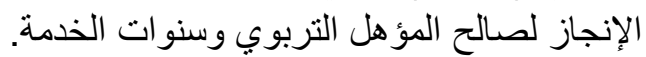

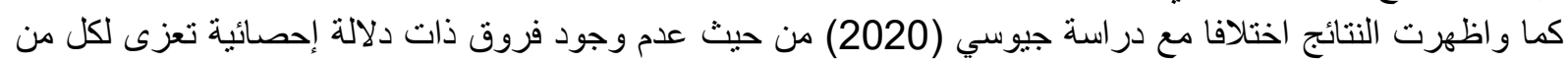
متغير المادة الدر اسية وسنوات الخدمة.

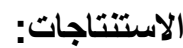

إن اتجاهات معلمي المرحلة الثانوية بالقدس الثرقية نحو نوظيف ملف الانجاز كأداة تقّويم بديل كانت إيجابية، و هذا يعكس و ويهم بأهمية نوظيف استراتيجية استعمال ملف الانجاز في التدريس لما لها من انعكاسات كبيرة في عمليتي التعليم و التعلم.

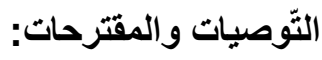

ـ ضرورة الانتقال من التقويم التقليدي والبدء بتطبيق ملف الإنجاز كأداة تقويم بديل في المدارس بالمراحل الأساسية والثانوية.

ـ البدء بعقد دور ات تدريبية للمعلمين الجدد و القدامى في جميع مدارس التربية و التعليم العالي.

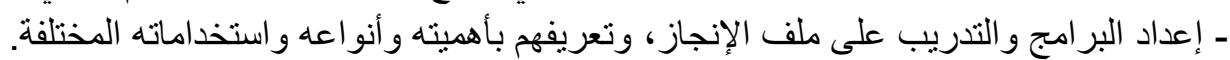

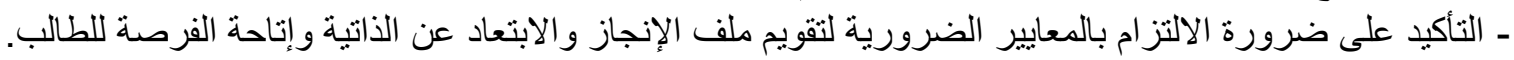

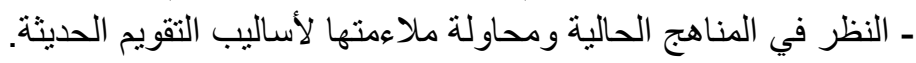

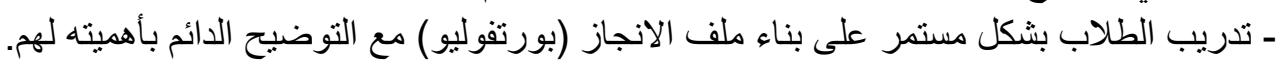

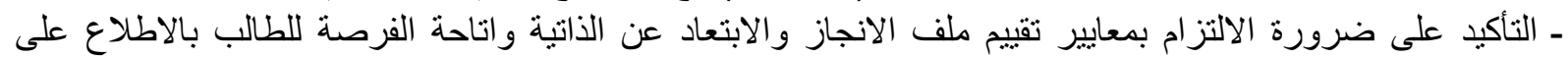
ملفه. - ــرورة معالجة نقاط ضعف الطالب أول بأول عند تسليم ملف الإنجاز بشكل دوري. - مقترحات لدر اسات مستقبلية - عمل در اسات أخرى تفحص اتجاهات الطلبة نحو التحو ملف الانجاز (البورتفوليو). ـ عمل دراسات اخرى تفحص اتجاهات ادار ات التعليم العالي نحو اعنبار ملف الانجاز التهاز أحد معايير القبول. 
ابراهيم ناصر، عاطف بن طريف، و محمد الزيون. (2014). مدخل إلى التربية، ط3. عمان - الأردن: دار الفكر العربي.

الكيلاني، و آخرون. (2014). القياس و التقويم في التعلم و التعليم. عمان: جامعة القسس المفتوحة.

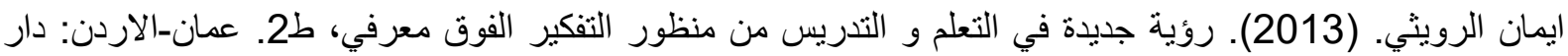

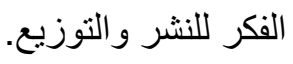

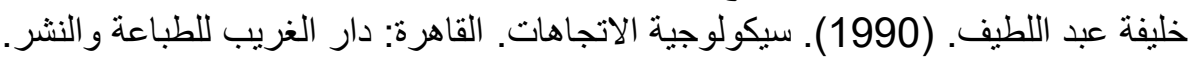
زكريا ابو الفيعات. (2011). اعداد وتاهيل المعلمين والاسس التربوية والنفسية، ط2. عمان-الاردن: دار الفكر للنشر

$$
\text { والتوزيع. }
$$

سلوى عثمان، و هبه الدغيدي. (2007). العلاقة بين تحقيق أغراض الحقيبة الوثائقية البورتفوليو والقدرة على الحوار

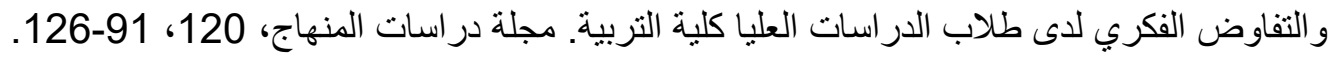

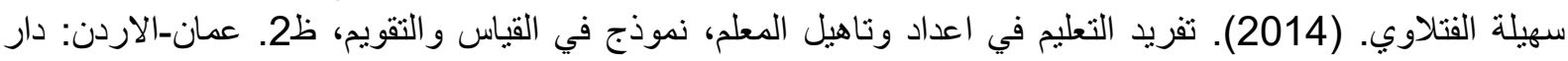
الشروق.

صلاح الدين علام. (2014). الاختبار ات و المقايس التربوية والنفسية. عمان ـالاردن: دار الفكر للنشر و التوزيع.

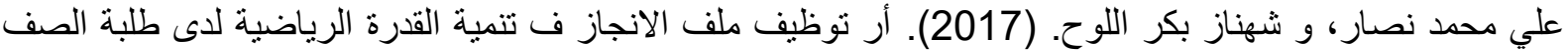

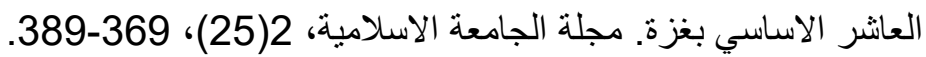

عوض أحمد الزبيدي. (2011). واقع استخدام اساليب التقييم البديل لدى معلمي ومعلمات محافظة الليثي. جامعة

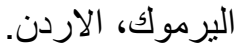

مجدي جيوسي. (2020). اتجاهات المعلمين نحو استخدام ملف الانجاز كاداة تقييم بديلة في مدارس جنوب نابلس. مجلة

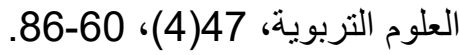

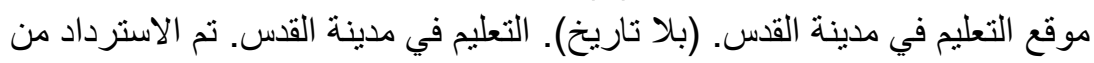
https://www. jerusalem. muni. il/ar/residents/education/elementaryschools/

هيام مصطفى عبد الله سالم. (2015). استخدام البورتفوليو كاستراتيجية التقييم البديل في كل من التفكير التأملي وأداء

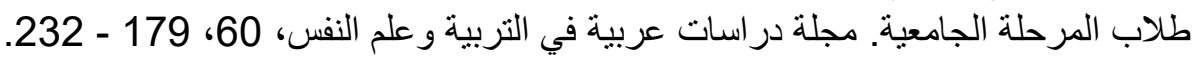

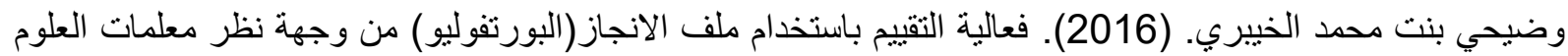
والطالبات في الصف الساد واولياء امورهن في المرحلة الابندائية. مجلة رابطة النئة النربية الحديثة،

.286-217، (28)8

\section{References:}

Craw, K. (2009). Performance Assesment Practices, a case study of Science Teacher in Suban High school Setting. United State, New York: Teacher College, Columbia university.

Grace, C. (1992). The Portfolio and Its Use:Developmentally Appropriate Assesment of Young Children. USA: Erec Digest.

Izci, K., \& Caliskan, G. (2017). Development Of Prospective Teachers" Conceptions of Assesment and Choices of Assesment Tasks. International Journal of Research in Education nd Science, 3(2), 465-474.

Kilbane, C., \& Milman, N. (2017). Examing The Impact of The Creation of Digital Portfolios by Highschool Teachers and Teir Students in Teachining and Learning. International Journal of ePortfolio(IJeP), 7(1), 101-109. 
McLaughlin, J., \& Lewes, R. (1994). Assessing Special Students. Macmillan College Publishing Company, Inc.

Mueller, J. (2009). Authentic Assessment Toolbox. Retrieved 2 17, 2019, from www,fmueller. noctrl

Office of Research. (1993). Student Portfolios: Dminstratative Uses. Office Of Educational Research and Improvement (OERI)of the U. S. Department of Education.

Samuel, S., \& Farstrup, A. (1995). What Research Has To Say About Reading Instruction(2nd ed. ). International Reading Association,Inc.

Smith, K., \& Harm, T. (2003, December). Clarrifying Different Types Of Portfolio Use Assesment and Evaluation in Higher Education. 28.

Sweet, D. (1993). Student Portfolios:Classroom Uses. Office of Educational Research And ImprovementOERI) of the U. S. Departement of Education. 